\title{
Glycemic Efficacy, Weight Effects, and Safety of Once-Weekly Glucagon-Like Peptide-1 Receptor Agonists
}

\author{
Yehuda Handelsman, MD, FACP, FNLA, FASPC, MACE; Kathleen Wyne, MD, PhD, FACE, FNLA \\ Anthony Cannon, MD, FACE; Michael Shannon, MD; and Doron Schneider, MD, FACP
}

\begin{abstract}
This article provides an overview of the efficacy and safety of once-weekly glucagon-like peptide-1 receptor agonists (GLP-1 RAs) in the treatment of type 2 diabetes mellitus (T2DM). GLP-1 RAs stimulate pancreatic GLP-1 receptors, which increases insulin secretion, delays gastric emptying, and increases satiety. As a class, GLP-1 RAs lower A1c levels and have been associated with reductions in weight and blood pressure and reduced fluctuations in glucose levels, and they have a low risk of hypoglycemia. Exenatide extended release (ER) and dulaglutide monotherapy have shown similar or superior reductions in A1c and weight compared with various oral antidiabetic drugs (OADs). Semaglutide has been shown to reduce both A1c and body weight compared with placebo and, in head-to-head studies versus both exenatide ER and dulaglutide, showed greater reductions in A1c and body weight. Once-weekly GLP-1 RAs have also been evaluated as add-on therapy in the continuum of care for the treatment of T2DM in combination with a variety of background medications, including 1 or more OADs (metformin, sulfonylureas, and/or thiazolidinediones), basal insulin, and prandial insulin. Gastrointestinal adverse events (e.g., nausea, vomiting, and diarrhea) are the most common side effects with once-weekly GLP-1 RAs. Rates of hypoglycemia, and especially major/severe hypoglycemia, are low with once-weekly GLP-1 RAs but, as expected, are higher when used in combination with sulfonylureas or insulin. These once-weekly GLP-1 RAs provide a safe and effective treatment option for patients with T2DM and may offer improved convenience and possibly greater adherence compared with daily GLP-1 RAs.
\end{abstract}

J Manag Care Spec Pharm. 2018;24(9-a):S14-S29

Copyright $\odot 2018$, Academy of Managed Care Pharmacy. All rights reserved.

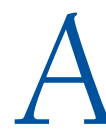

chieving and maintaining good glycemic control is an ongoing challenge in the management of patients with type 2 diabetes mellitus (T2DM), and current trends are not encouraging. Analysis of claims data from privately insured and Medicare Advantage patients with T2DM revealed that, between 2006 and 2013, the proportion of patients with glycated hemoglobin (Alc) $<7 \%$ declined from $56.4 \%$ to $54.2 \%$, while the proportion of those with Alc $\geq 9 \%$ increased from $9.9 \%$ to $12.2 \%$; the rate of severe hypoglycemia remained stable during this period (1.3 per 100 person-years). ${ }^{1}$

Specific aims of T2DM management include achieving and maintaining good glycemic control while minimizing the risk of adverse effects, particularly hypoglycemia and weight gain, both of which are highly undesirable and not uncommon side effects of some antidiabetic medications. ${ }^{2,3}$ Clinical inertia-the resistance to initiating or adjusting treatment strategies in a timely manner as recommend by the American Diabetes Association and American Association of Clinical Endocrinologists guidelines-is another barrier to achieving glycemic goals. ${ }^{4,5}$ Recently, newer therapeutic agents with different mechanisms of action that mitigate the risks of hypoglycemia and weight gain have become available and may help overcome clinical inertia in the treatment of T2DM.

Glucagon-like peptide-1 receptor agonists (GLP-1 RAs) are analogs of endogenous GLP-1 that stimulate the GLP-1 receptor on pancreatic beta cells to increase glucose-dependent insulin secretion, delay gastric emptying, and increase satiety. ${ }^{2,6,7}$ As a class, GLP-1 RAs lower Alc levels and are usually associated with reductions in weight and blood pressure. ${ }^{3}$ These agents also reduce fluctuations in glucose levels and are associated with a low risk of hypoglycemia. ${ }^{3}$ The recommended timing for initiation of GLP-1 RA therapy in patients with T2DM is early (after, ${ }^{2}$ or as an alternative to, ${ }^{3}$ initial treatment with metformin) and throughout the course of therapy. ${ }^{2,3}$

Exenatide (twice daily; Byetta; AstraZeneca Pharmaceuticals, Wilmington, DE) and liraglutide (Victoza; Novo Nordisk, Plainsboro, NJ), approved by the U.S. Food and Drug Administration (FDA) in 2005 and 2010, respectively, were the first GLP-1 RAs available in the United States. ${ }^{8,9}$ Lixisenatide (Adlyxin; Sanofi-Aventis U.S., Bridgewater, NJ) was approved in 2016. ${ }^{10}$ These GLP-1 RAs are administered via subcutaneous (SC) injection once (liraglutide and lixisenatide) or twice (exenatide) daily. Several once-weekly GLP-1 RAs have been developed and FDA approved since 2012 (Table 1). An extended-release (ER), once-weekly injectable formulation of exenatide (Bydureon; AstraZeneca Pharmaceuticals, Wilmington, DE) was approved in 2012. ${ }^{11}$ In 2014, the FDA approved the once-weekly GLP-1 RA dulaglutide (Trulicity; Eli Lilly and Company, Indianapolis, IN). ${ }^{12}$ Semaglutide (Ozempic; Novo Nordisk, Plainsboro, NJ) ${ }^{13}$ was FDA approved in December 2017. Another once-weekly GLP-1 RA, albiglutide (Tanzeum; GlaxoSmithKline, Wilmington, DE), ${ }^{14}$ was approved in 2014, but production was discontinued in July 2018 due to a business decision unrelated to safety, ${ }^{15}$ so it will be not be discussed in detail here.

The purpose of this review is to provide an overview of the efficacy (with respect to glycemic control and body weight) and safety of once-weekly GLP-1 RAs. While cardiovascular safety and benefits are clearly important considerations, these topics are the focus of a designated article within this supplement and not detailed here.

\section{Overview of Once-Weekly GLP-1 RAs}

Table 1 summarizes the indications, limitations of use, dosing recommendations, contraindications, and warnings associated with once-weekly GLP-1 RAs. All once-weekly GLP-1 RAs are indicated as adjuncts to diet and exercise to improve glycemic 
TABLE 1 Overview of Once-Weekly GLP-1 RAs

\begin{tabular}{|c|c|c|c|}
\hline & Exenatide ER & Dulaglutide & Semaglutide \\
\hline \multicolumn{4}{|l|}{ Indication } \\
\hline Adjunct to diet and exercise to improve glycemic control in adults with T2DM & $x$ & $\times$ & $x$ \\
\hline \multicolumn{4}{|l|}{ Limitations of use } \\
\hline $\begin{array}{l}\text { Not recommended as first-line therapy for patients inadequately } \\
\text { controlled on diet and exercise }\end{array}$ & $x$ & $x$ & $\times$ \\
\hline Should not be used to treat TIDM or DKA & $\times$ & $\times$ & $\times$ \\
\hline Use with insulin not studied and not recommended & $\times$ & & \\
\hline Has not been studied in patients with a history of pancreatitis & $x$ & $x$ & $x$ \\
\hline Not for patients with preexisting severe gastrointestinal disease & $x$ & $\times$ & \\
\hline Dosage and administration & $2 \mathrm{mg} \mathrm{SC} \mathrm{QW}$ & $\begin{array}{l}0.75 \mathrm{mg} \mathrm{SC} \mathrm{QW} \text {; can } \\
\text { increase to } 1.5 \mathrm{mg} \\
\text { SC QW }\end{array}$ & $\begin{array}{c}0.25 \mathrm{mg} \mathrm{SC} \mathrm{QW} \text {; can } \\
\text { be increased at } 4 \text {-week } \\
\text { intervals to } 0.5 \mathrm{mg} \\
\mathrm{QW} \text {, then } 1 \mathrm{mg} \mathrm{QW}\end{array}$ \\
\hline \multicolumn{4}{|l|}{ Contraindications } \\
\hline Patients with personal or family history of medullary thyroid carcinoma & $x$ & $\times$ & $\times$ \\
\hline Patients with multiple endocrine neoplasia syndrome type 2 & $x$ & $x$ & $x$ \\
\hline Prior or serious hypersensitivity reaction to any of the product components & $\times$ & $\times$ & $x$ \\
\hline \multicolumn{4}{|l|}{ Warnings and precautions } \\
\hline Black-boxed warning: risk of thyroid C-cell tumors & $\times$ & $\times$ & $x$ \\
\hline Pancreatitis & $x$ & $\times$ & $x$ \\
\hline $\begin{array}{l}\text { When used in combination with an insulin secretagogue (e.g., a sulfonylurea) } \\
\text { or insulin, consider lowering the dose of the secretagogue or insulin to reduce } \\
\text { the risk of hypoglycemia }\end{array}$ & $x$ & $\times$ & $x$ \\
\hline Renal impairment/acute kidney injury & $\times$ & $\times$ & $x$ \\
\hline $\begin{array}{l}\text { Not recommended in patients with severe gastrointestinal disease } \\
\text { (e.g., gastroparesis) }\end{array}$ & $x$ & $x$ & \\
\hline Immunogenicity (antibodies) & $x$ & & \\
\hline Hypersensitivity reactions & $x$ & $x$ & $x$ \\
\hline $\begin{array}{l}\text { Postmarketing reports of serious injection-site reactions with or without } \\
\text { subcutaneous nodules }\end{array}$ & $x$ & & \\
\hline $\begin{array}{l}\text { No clinical studies establishing conclusive evidence of macrovascular } \\
\text { risk reduction }\end{array}$ & $x$ & $x$ & $x$ \\
\hline Patients with history of diabetic retinopathy should be monitored & & & $\times$ \\
\hline
\end{tabular}

DKA = diabetic ketoacidosis; $E R=$ extended-release; GLP-1 RA=glucagon-like peptide-1 receptor agonist; $Q \mathrm{~W}=$ once weekly; SC=subcutaneous; T1DM=type 1 diabetes mellitus; T2DM = type 2 diabetes mellitus.

control in adults with T2DM but are not recommended as initial therapy for patients inadequately controlled on diet and exercise. ${ }^{11,12,13}$ The recommended dosage of exenatide ER is 2 mg once weekly for all patients. In contrast, gradual dose titration is recommended as needed with albiglutide, dulaglutide, and semaglutide. Additionally, the labeling for each onceweekly GLP-1 RA carries a boxed warning regarding the risk of thyroid C-cell tumors based on findings in rodents. Each of the GLP-1 RAs is available as a prefilled syringe and/or pen.

\section{Review of Efficacy Findings}

Table 2 describes the study designs and key trial characteristics of pivotal trials for each once-weekly GLP-1 RA. Results for Alc and weight changes from baseline in clinical trials are displayed in Figure 1 and Figure 2, respectively.

\section{Exenatide ER}

When used as monotherapy (DURATION-4), exenatide ER $2.0 \mathrm{mg}$ administered once weekly reduced Alc by $1.5 \%$ from baseline to week 26; this effect was comparable to that of metformin (-1.5\%) and pioglitazone (-1.6\%) but statistically significantly superior to that of sitagliptin (-1.2\%). ${ }^{19}$ Treatment with exenatide ER $2.0 \mathrm{mg}$ once weekly was associated with a $2.0-\mathrm{kg}$ reduction in weight, which was comparable to the weight loss observed with metformin (2.0-kg reduction) and significantly superior to the weight effects of pioglitazone $(+1.5 \mathrm{~kg})$ and sitagliptin $(-0.8 \mathrm{~kg})$. As an add-on to metformin (DURATION-2), exenatide ER $2.0 \mathrm{mg}$ once weekly significantly reduced both Alc $(-1.5 \%)$ and weight $(-2.3 \mathrm{~kg})$ from baseline to 26 weeks compared with sitagliptin (Alc: $-0.9 \%$; body weight: $-0.8 \mathrm{~kg}$ ) and pioglitazone (Alc: $-1.2 \%$; body weight: $+2.8 \mathrm{~kg}$ ). ${ }^{17}$ DURATION-3 compared exenatide ER $2.0 \mathrm{mg}$ once weekly 
TABLE 2 Summary of Published Once-Weekly GLP-1 RA Pivotal Clinical Trial Data (Efficacy)

\begin{tabular}{|c|c|c|c|}
\hline Study & Study Design & Treatment Groups & Background Pharmacotherapy \\
\hline \multicolumn{4}{|l|}{ Exenatide ER } \\
\hline DURATION-1 16 & $\begin{array}{l}\text { 30-week, multicenter, randomized, } \\
\text { open-label noninferiority study } \\
\text { (3-day lead-in with exenatide } 5 \mu \mathrm{g} \\
\text { BID prior to receiving assigned } \\
\text { treatment) }\end{array}$ & $\begin{array}{l}\text { - Exenatide ER SC } 2 \text { mg QW }(\mathrm{n}=148) \\
\text { - Exenatide SC } 5 \mu \mathrm{g} \text { BID for first } 4 \text { weeks, then } 10 \mu \mathrm{g} \\
\text { BID for remainder of study }(\mathrm{n}=147)\end{array}$ & $\begin{array}{l}\text { None or metformin, a sulfonylurea, } \\
\text { a TZD, or any combination of } 2 \text { of } \\
\text { these agents }\end{array}$ \\
\hline DURATION-217 & $\begin{array}{l}\text { 26-week, multicenter, randomized, } \\
\text { double-blind, double-dummy study }\end{array}$ & $\begin{array}{l}\text { - Exenatide ER SC } 2 \text { mg QW }(n=170) \\
\text { - Sitagliptin oral } 100 \text { mg QD }(n=172) \\
\text { - Pioglitazone oral } 45 \text { mg QD }(n=172)\end{array}$ & Metformin \\
\hline DURATION-318 & $\begin{array}{l}\text { 26-week, multicenter, randomized, } \\
\text { open-label study }\end{array}$ & $\begin{array}{l}\text { - Exenatide ER SC } 2 \mathrm{mg} \text { QW }(\mathrm{n}=233) \\
\text { - Insulin glargine SC } 10 \mathrm{IU} \text { QD adjusted to achieve } \\
\text { target glucose of } 4.0-5.5 \mathrm{mmol} / \mathrm{L}(\mathrm{n}=223)\end{array}$ & Metformin $\geq 1,500 \mathrm{mg} / \mathrm{d} \pm$ sulfonylurea \\
\hline DURATION-419 & $\begin{array}{l}\text { 26-week, multicenter, randomized, } \\
\text { placebo-controlled, double-blind, } \\
\text { double-dummy study }\end{array}$ & $\begin{array}{l}\text { - Exenatide ER SC } 2 \mathrm{mg} \text { QW }(\mathrm{n}=248) \\
\text { - Metformin oral 2,000 mg/d (could be increased up } \\
\text { to } 2,500 \mathrm{mg} / \mathrm{d} \text { based on glycemic control; } \mathrm{n}=246) \\
\text { - Pioglitazone oral } 45 \mathrm{mg} / \mathrm{d}(\mathrm{n}=163) \\
\text { - Sitagliptin oral } 100 \mathrm{mg} / \mathrm{d}(\mathrm{n}=163)\end{array}$ & None \\
\hline DURATION-520 & $\begin{array}{l}\text { 24-week, multicenter, randomized, } \\
\text { open-label study }\end{array}$ & $\begin{array}{l}\text { - Exenatide ER SC } 2 \text { mg QW }(\mathrm{n}=129) \\
\text { - Exenatide SC } 5 \mu \mathrm{g} \text { BID for first } 4 \text { weeks, then } 10 \mu \mathrm{g} \\
\text { BID for remainder of study }(\mathrm{n}=123)\end{array}$ & $\begin{array}{l}\text { None or a stable, maximally effective } \\
\text { regimen of metformin, sulfonylurea, } \\
\text { TZD, or a combination of these } \\
\text { medications }\end{array}$ \\
\hline DURATION-621 & $\begin{array}{l}\text { 26-week, multicenter, randomized, } \\
\text { open-label study }\end{array}$ & $\begin{array}{l}\text { - Exenatide ER SC } 2 \text { mg QW (n=461) } \\
\text { - Liraglutide SC titrated to } 1.8 \mathrm{mg} \text { QD }(\mathrm{n}=450)\end{array}$ & $\begin{array}{l}\text { Metformin, sulfonylurea, } \\
\text { metformin + sulfonylurea, or } \\
\text { metformin + pioglitazone }\end{array}$ \\
\hline DURATION-722 & $\begin{array}{l}\text { 28-week, multicenter, randomized, } \\
\text { double-blind, placebo-controlled, } \\
\text { parallel group study }\end{array}$ & $\begin{array}{l}\text { - Exenatide ER SC } 2 \text { mg QW }(\mathrm{n}=231) \\
\text { - Placebo }(\mathrm{n}=230)\end{array}$ & $\begin{array}{l}\text { Insulin glargine with/without } \\
\text { metformin }\end{array}$ \\
\hline DURATION-823 & $\begin{array}{l}\text { 28-week, multicenter, randomized, } \\
\text { double-blind study }\end{array}$ & $\begin{array}{l}\text { - Exenatide ER SC } 2 \text { mg QW + dapagliflozin oral } 10 \\
\text { mg QD }(n=231) \\
\text { - Exenatide ER SC } 2 \mathrm{mg} \mathrm{QW} \mathrm{(n=231)} \mathrm{plus} \mathrm{placebo} \\
\text { - Dapagliflozin oral } 10 \mathrm{mg} \text { QD }(\mathrm{n}=233) \text { plus placebo }\end{array}$ & $\begin{array}{l}\text { Stable regimen of metformin } \\
(\geq 1,500 \mathrm{mg} / \text { day })\end{array}$ \\
\hline \multicolumn{4}{|l|}{ Dulaglutide } \\
\hline AWARD-124 & $\begin{array}{l}\text { 52-week multicenter, randomized } \\
\text { double-blind, placebo-controlled } \\
\text { study (placebo-treated patients } \\
\text { switched to dulaglutide } 0.75 \text { or } \\
1.5 \mathrm{mg} \text { QW after } 26 \text { weeks; primary } \\
\text { endpoint, } 26 \text { weeks) }\end{array}$ & $\begin{array}{l}\text { - Dulaglutide SC } 0.75 \mathrm{mg} \text { QW }(\mathrm{n}=280) \\
\text { - Dulaglutide SC } 1.5 \mathrm{mg} \text { QW }(\mathrm{n}=279) \\
\text { - Exenatide SC } 5 \mu \mathrm{g} \text { BID for first } 4 \text { weeks, then } 10 \mu \mathrm{g} \\
\text { BID for remainder of study }(\mathrm{n}=276) \\
\text { - Placebo }(\mathrm{n}=141)\end{array}$ & $\begin{array}{l}\text { Metformin }(1,500-3,000 \mathrm{mg} / \mathrm{d}) \text { and } \\
\text { pioglitazone }(30-45 \mathrm{mg} / \mathrm{d})\end{array}$ \\
\hline AWARD-225 & $\begin{array}{l}78 \text {-week, multicenter, randomized, } \\
\text { open-label (blind to dulaglutide } \\
\text { dose) study (primary endpoint, } \\
52 \text { weeks) }\end{array}$ & $\begin{array}{l}\text { - Dulaglutide SC } 0.75 \mathrm{mg} \text { QW }(\mathrm{n}=272) \\
\text { - Dulaglutide SC } 1.5 \mathrm{mg} \text { QW ( } \mathrm{n}=273) \\
\text { - Insulin glargine SC } 10 \mathrm{IU} \text { QD adjusted to achieve } \\
\text { target glucose }<5.6 \mathrm{mmol} / \mathrm{L}(\mathrm{n}=262)\end{array}$ & $\begin{array}{l}\text { Metformin }(1,500 \mathrm{mg} / \mathrm{d}) \text { and } \\
\text { glimepiride }(4 \mathrm{mg} / \mathrm{d}) \text {; both could } \\
\text { be increased to maximum locally } \\
\text { approved doses }\end{array}$ \\
\hline AWARD-326 & $\begin{array}{l}\text { 52-week, multicenter, randomized, } \\
\text { double-blind, double-dummy non- } \\
\text { inferiority study (primary endpoint, } \\
26 \text { weeks) }\end{array}$ & $\begin{array}{l}\text { - Dulaglutide SC } 0.75 \mathrm{mg} \text { QW ( }=270) \\
\text { - Dulaglutide SC } 1.5 \mathrm{mg} \text { QW ( } \mathrm{n}=269) \\
\text { - Metformin oral 2,000 mg/d (at least 1,500 depending } \\
\text { on tolerability; } \mathrm{n}=268)\end{array}$ & None \\
\hline AWARD-427 & $\begin{array}{l}\text { 52-week, multicenter, randomized, } \\
\text { open-label noninferiority study } \\
\text { (primary endpoint, } 26 \text { weeks) }\end{array}$ & $\begin{array}{l}\text { - Dulaglutide SC } 0.75 \text { mg QW }(\mathrm{n}=293) \\
\text { - Dulaglutide SC } 1.5 \mathrm{mg} \text { QW }(\mathrm{n}=295) \\
\text { - Insulin glargine SC adjusted based on a } \\
\text { treat-to-target strategy }(\mathrm{n}=296)\end{array}$ & $\begin{array}{l}\text { Prandial insulin lispro } \pm \text { metformin } \\
\geq 1,500 \mathrm{mg} / \mathrm{d}\end{array}$ \\
\hline AWARD -528 & $\begin{array}{l}\text { 104-week, multicenter, randomized, } \\
\text { double-blind, placebo-controlled } \\
\text { study; randomized dose-finding } \\
\text { period for dulaglutide followed } \\
\text { by randomized fixed-dose period } \\
\text { (primary endpoint, } 52 \text { weeks) }\end{array}$ & $\begin{array}{l}\text { - Dulaglutide SC } 0.75 \text { mg QW }(\mathrm{n}=302) \\
\text { - Dulaglutide SC } 1.5 \mathrm{mg} \text { QW }(\mathrm{n}=304) \\
\text { - Sitagliptin, oral } 100 \mathrm{mg} \text { QD }(\mathrm{n}=315) \\
\text { - Placebo, replaced with sitagliptin } 100 \mathrm{mg} \text { QD after } \\
26 \text { weeks ( }=177)\end{array}$ & Metformin $\geq 1,500 \mathrm{mg} / \mathrm{d}$ \\
\hline
\end{tabular}




\begin{tabular}{|c|c|c|c|}
\hline Study & Study Design & Treatment Groups & Background Pharmacotherapy \\
\hline \multicolumn{4}{|l|}{ Dulaglutide } \\
\hline AWARD- 629 & $\begin{array}{l}\text { 26-week, multicenter, randomized, } \\
\text { open-label noninferiority study }\end{array}$ & $\begin{array}{l}\text { - Dulaglutide SC } 1.5 \text { mg QW (n=299) } \\
\text { - Liraglutide SC } 1.8 \text { mg QD }(n=300)\end{array}$ & Metformin $\geq 1,500 \mathrm{mg} / \mathrm{d}$ \\
\hline AWARD-8 30 & $\begin{array}{l}\text { 24-week, multicenter, randomized, } \\
\text { double-blind, placebo-controlled } \\
\text { study }\end{array}$ & $\begin{array}{l}\text { - Dulaglutide SC } 1.5 \text { mg QW (n=240) } \\
\text { - Placebo }(n=60)\end{array}$ & Glimepiride \\
\hline AWARD-931 & $\begin{array}{l}\text { 28-week, multicenter, randomized, } \\
\text { double-blind, placebo-controlled } \\
\text { study }\end{array}$ & $\begin{array}{l}\text { - Dulaglutide SC } 1.5 \text { mg QW ( } n=150) \\
\text { - Placebo }(n=150)\end{array}$ & $\begin{array}{l}\text { Insulin glargine once-daily titrated to } \\
\text { target } \pm \text { metformin }\end{array}$ \\
\hline \multicolumn{4}{|l|}{ Semaglutide } \\
\hline SUSTAIN-1 ${ }^{32}$ & $\begin{array}{l}\text { 30-week, multicenter, randomized, } \\
\text { double-blind, placebo-controlled } \\
\text { study }\end{array}$ & $\begin{array}{l}\text { - Semaglutide SC } 0.5 \text { mg QW ( }=128) \\
\text { - Semaglutide SC } 1.0 \text { mg QW ( }=130) \\
\text { - Placebo }(n=129)\end{array}$ & None \\
\hline SUSTAIN-233 & $\begin{array}{l}\text { 56-week, multicenter, random- } \\
\text { ized, double-blind, double-dummy, } \\
\text { placebo-controlled study }\end{array}$ & $\begin{array}{l}\text { - Semaglutide SC } 0.5 \text { mg QW ( }=409) \\
\text { - Semaglutide SC } 1.0 \text { mg QW ( }=409) \\
\text { - Sitagliptin oral } 100 \text { mg QD }(n=407)\end{array}$ & $\begin{array}{l}\text { Metformin ( } \geq 1,500 \mathrm{mg} \text { ), pioglitazone } \\
\text { ( } \geq 30 \mathrm{mg} \text { ), rosiglitazone } \\
(\geq 4 \mathrm{mg} \text { ), or a combination of } \\
\text { either metformin + pioglitazone or } \\
\text { metformin + rosiglitazone }\end{array}$ \\
\hline SUSTAIN-334 & $\begin{array}{l}\text { 56-week, multicenter, randomized, } \\
\text { open-label study }\end{array}$ & $\begin{array}{l}\text { - Semaglutide SC } 1.0 \text { mg QW ( }=404) \\
\text { - Exenatide ER SC } 2.0 \text { mg QW ( } \mathrm{n}=405)\end{array}$ & $\begin{array}{l}\text { 1-2 OADs, including metformin, } \\
\text { sulfonylureas, and/or TZDs }\end{array}$ \\
\hline SUSTAIN-435 & $\begin{array}{l}\text { 30-week, multicenter, randomized, } \\
\text { open-label noninferiority study }\end{array}$ & $\begin{array}{l}\text { - Semaglutide SC } 0.5 \mathrm{mg} \text { QW }(\mathrm{n}=362) \\
\text { - Semaglutide SC } 1.0 \mathrm{mg} \text { QW }(\mathrm{n}=360) \\
\text { - Insulin glargine SC } 10 \mathrm{IU} \text { QD adjusted to achieve } \\
\text { target glucose of 4.0-5.5 mmol/L }(\mathrm{n}=360)\end{array}$ & Metformin \pm sulfonylurea \\
\hline SUSTAIN-536 & $\begin{array}{l}\text { 30-week, multicenter randomized, } \\
\text { double-blind, placebo-controlled } \\
\text { study }\end{array}$ & $\begin{array}{l}\text { - Semaglutide SC } 0.5 \text { mg QW ( } n=132) \\
\text { - Semaglutide SC } 1.0 \text { mg QW ( } n=131) \\
\text { - Placebo }(n=133)\end{array}$ & Basal insulin \pm metformin \\
\hline SUSTAIN-737 & $\begin{array}{l}40 \text {-week, randomized, open-label } \\
\text { study }\end{array}$ & $\begin{array}{l}\text { - Semaglutide SC 0.5 mg QW ( } \mathrm{n}=301) \\
\text { - Semaglutide SC } 1.0 \mathrm{mg} \text { QW ( } \mathrm{n}=300) \\
\text { - Dulaglutide SC } 0.75 \mathrm{mg} \text { QW ( } \mathrm{n}=299) \\
\text { - Dulaglutide SC } 1.5 \mathrm{mg} \text { QW }(\mathrm{n}=299)\end{array}$ & $\begin{array}{l}\text { Metformin ( } \geq 1,500 \mathrm{mg} \text { or maximum } \\
\text { tolerated dose) }\end{array}$ \\
\hline
\end{tabular}

$B I D=$ twice daily; ER=extended-release; GLP-1 RA=glucagon-like peptide-1 receptor agonist; $I U=$ international unit; OAD=oral antidiabetic drug; $Q D=$ once daily; QW =once weekly; $S C=$ subcutaneous; TZD = thiazolidinedione.

with insulin glargine, both as add-on to metformin \pm sulfonylurea. ${ }^{18}$ At 26 weeks, exenatide once weekly significantly reduced Alc compared with insulin glargine (-1.5\% vs. $-1.3 \%)$ and was associated with a significantly greater reduction in body weight $(-2.6 \mathrm{~kg}$ vs. $+1.4 \mathrm{~kg})$.

Two studies compared exenatide ER $2.0 \mathrm{mg}$ once weekly with exenatide $10 \mu \mathrm{g}$ twice daily as monotherapy or as addon to oral antidiabetic drugs (OADs; DURATION-1 and DURATION-5). ${ }^{16,20}$ In both of these studies, exenatide ER produced a significantly greater reduction in Alc than exenatide (DURATION-1: $-1.9 \%$ vs. $-1.5 \%$; DURATION-5: $-1.6 \%$ vs. $-0.9 \%) .^{16,20}$ Notably, exenatide ER treatment produced a significantly greater reduction in fasting plasma glucose compared with exenatide in both DURATION-1 (change from baseline to week 30: -41 vs. $-25 \mathrm{mg} / \mathrm{dL} ; P<0.0001)$ and DURATION-5 (change from baseline to week 24: -35 vs. -12 $\mathrm{mg} / \mathrm{dL} ; \quad P=0.0008)$. In DURATION-1, both exenatide ER and exenatide reduced postprandial glucose at baseline and week 30, with similar reductions observed at baseline; however, the effect of exenatide ER (but not that of exenatide) on postprandial glucose was blunted by week $30^{16}$; postprandial glucose was not assessed in DURATION-5. Reductions in body weight were observed through the primary endpoints of both studies, with no significant difference between formulations (DURATION-1: $-3.7 \mathrm{~kg}$ vs. $-3.6 \mathrm{~kg}$; DURATION-5: $-2.3 \mathrm{~kg}$ vs. $-1.4 \mathrm{~kg}) .16,20$

DURATION-6 compared exenatide ER with the oncedaily GLP-1 RA liraglutide as add-on therapy to metformin, a sulfonylurea, metformin + sulfonylurea, or metformin + pioglitazone. ${ }^{21}$ Both liraglutide and exenatide ER lowered Alc and body weight from baseline, although both changes were significantly greater with liraglutide (Alc: $-1.3 \%$ exenatide ER vs. $-1.5 \%$ liraglutide, $P=0.02$; body weight: $-2.7 \mathrm{~kg}$ exenatide ER vs. $-3.6 \mathrm{~kg}$ liraglutide, $P=0.02$ ). 
FIGURE 1 Changes in Alc from Baseline in Once-Weekly GLP-1 RA Studies for Exenatide ER, Dulaglutide, and Semaglutide

\section{A. Exenatide ER}

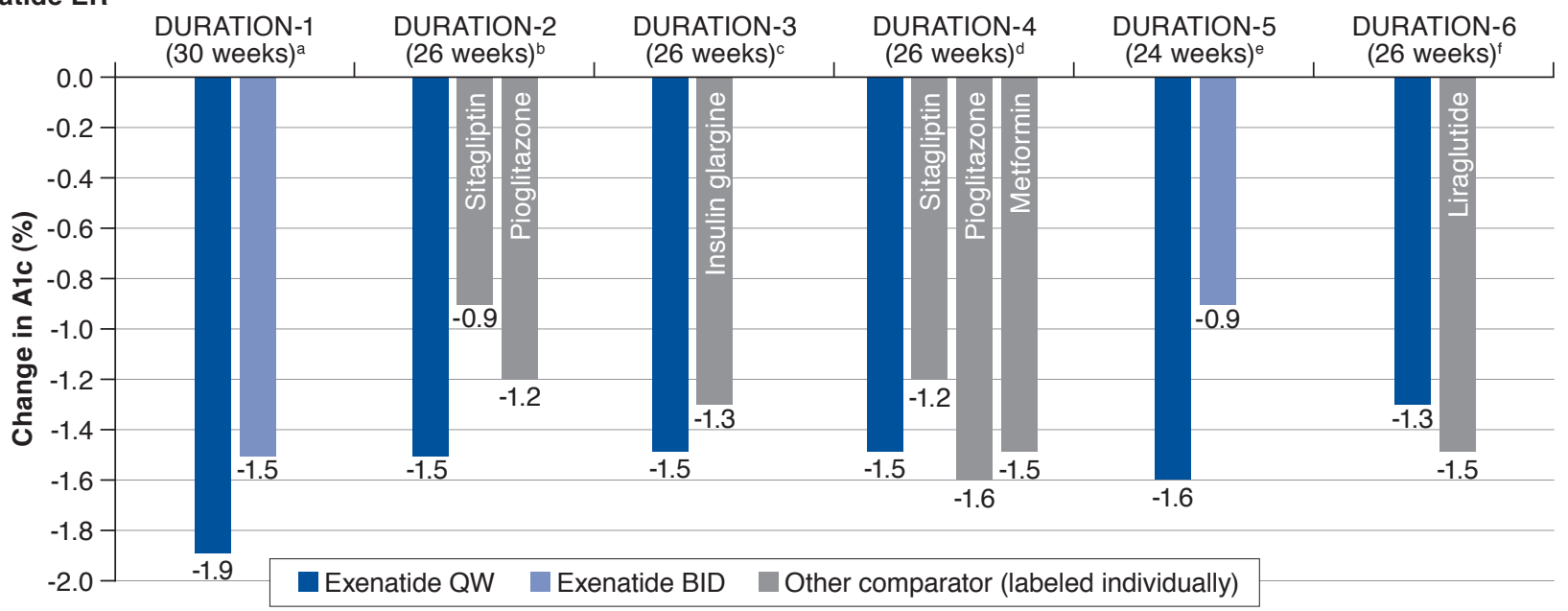

B. Dulaglutide

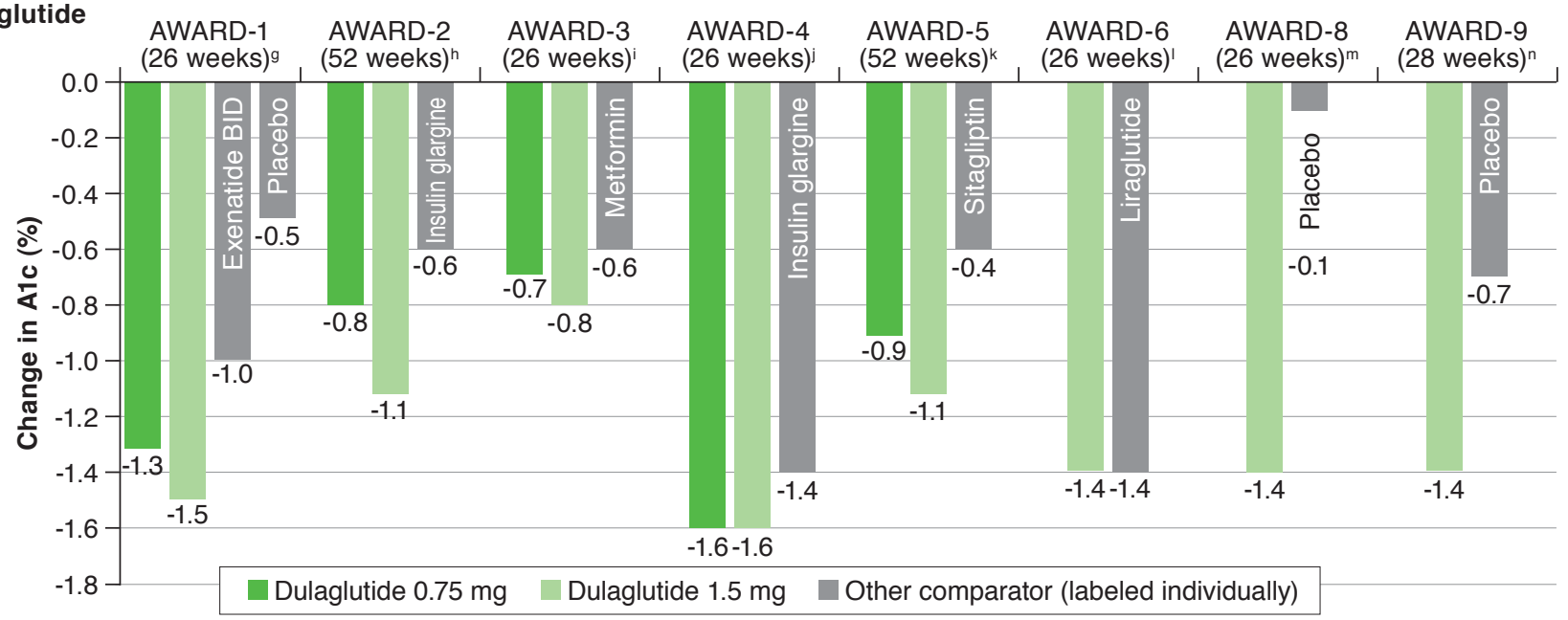

\section{Dulaglutide}

As monotherapy (AWARD-3), dulaglutide $0.75 \mathrm{mg}(-0.7 \%)$ and $1.5 \mathrm{mg}(-0.8 \%)$ both reduced Alc from baseline to week 26 to a slightly but significantly greater degree than metformin $(-0.6 \%) .{ }^{26}$ Reduction in body weight was similar for dulaglutide $1.5 \mathrm{mg}(-2.3 \mathrm{~kg})$ and metformin $(-2.2 \mathrm{~kg})$ but was significantly less pronounced with dulaglutide $0.75 \mathrm{mg}(-1.4 \mathrm{~kg})$ versus metformin. Two studies evaluated dulaglutide as add-on therapy to metformin in comparison with sitagliptin (AWARD-5) and liraglutide (AWARD-6). ${ }^{28,29}$ In AWARD-5, patients randomized to placebo were switched to sitagliptin after 26 weeks; the primary endpoint was 52 weeks. At 26 weeks, change in Alc was $-1.0 \%$ for dulaglutide $0.75 \mathrm{mg}(P<0.001 \mathrm{vs}$. sitagliptin and placebo), $-1.2 \%$ for dulaglutide $1.5 \mathrm{mg}(P<0.001$ vs. sitagliptin and placebo), $-0.6 \%$ for sitagliptin $(P<0.001$ vs. placebo), and $0.03 \%$ for placebo. There was a mean reduction in body weight of $2.7 \mathrm{~kg}$ for dulaglutide $0.75 \mathrm{mg}(P<0.001 \mathrm{vs}$. sitagliptin and placebo), $3.0 \mathrm{~kg}$ for dulaglutide $1.5 \mathrm{mg}(P<0.001$ vs. sitagliptin and placebo), $1.4 \mathrm{~kg}$ for sitagliptin, and $1.4 \mathrm{~kg}$ for placebo. ${ }^{12}$ From baseline to week 52, both dulaglutide 0.75 $\mathrm{mg}$ and $1.5 \mathrm{mg}$ produced significantly greater improvements in both Alc and body weight compared with sitagliptin (Alc: $-0.9 \%$ [dulaglutide $0.75 \mathrm{mg}$ ], $-1.1 \%$ [dulaglutide $1.5 \mathrm{mg}$ ], $-0.4 \%$ [sitagliptin]; body weight: $-2.6 \mathrm{~kg}$ [dulaglutide $0.75 \mathrm{mg}$ ], -3.0 $\mathrm{kg}$ [dulaglutide $1.5 \mathrm{mg}$ ], $-1.5 \mathrm{~kg}$ [sitagliptin]). ${ }^{28}$ Dulaglutide 1.5 $\mathrm{mg}$ and liraglutide reduced Alc from baseline to week 26 to a 
FIGURE 1 Changes in Alc from Baseline in Once-Weekly GLP-1 RA Studies for Exenatide ER, Dulaglutide, and Semaglutide (continued)

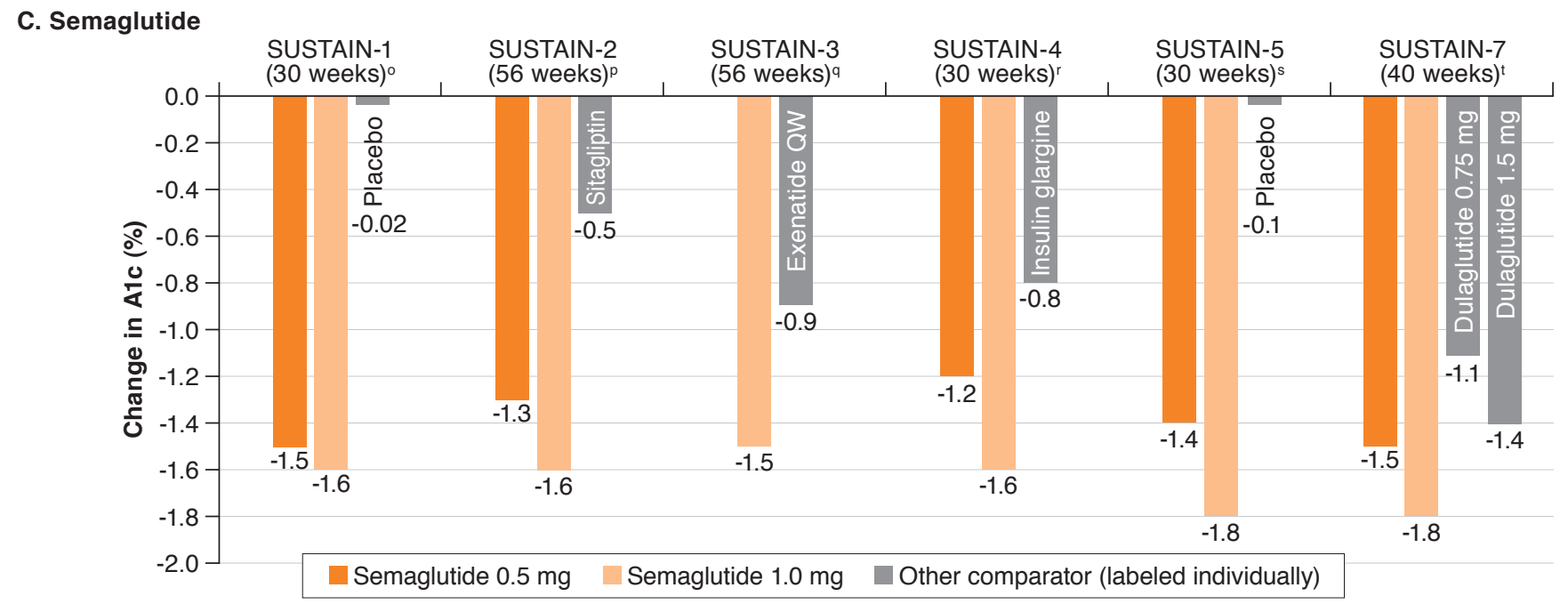

$a P=0.0023$.

${ }^{b} P<0.0001$ vs. sitagliptin. $P=0.0165$ vs. pioglitazone.

${ }^{c} P=0.017$.

$d P<0.001$ vs. sitagliptin. $P=N S$ vs. metformin and pioglitazone.

eP $<0.001$

$f_{P}=0.02$.

gDulaglutide $0.75 \mathrm{mg}$ vs. exenatide BID and vs. placebo: $P<0.001$. Dulaglutide $1.5 \mathrm{mg}$ vs. exenatide BID and vs. placebo: $P<0.001$

${ }^{h}$ Dulaglutide $0.75 \mathrm{mg}$ vs. insulin glargine: $P=$ NS. Dulaglutide $1.5 \mathrm{mg}$ vs. insulin glargine: $P<0.001$.

${ }^{i}$ Dulaglutide $0.75 \mathrm{mg}$ vs. metformin: $P=0.02$. Dulaglutide $1.5 \mathrm{mg}$ vs. metformin: $P=0.002$.

jDulaglutide $0.75 \mathrm{mg}$ vs. insulin glargine: $P=0.015$. Dulaglutide $1.5 \mathrm{mg}$ vs. insulin glargine: $P=0.005$.

${ }^{k}$ Dulaglutide $0.75 \mathrm{mg}$ vs. sitagliptin: $P<0.001$. Dulaglutide $1.5 \mathrm{mg}$ vs. sitagliptin: $P<0.001$.

$l^{l} P=N S$.

$m P<0.001$

$n P<0.001$

oSemaglutide $0.5 \mathrm{mg}$ : $P<0.0001$ vs. placebo. Semaglutide $1.0 \mathrm{mg}$ : $P<0.0001$ vs. placebo.

pSemaglutide $0.5 \mathrm{mg}$ : $P<0.0001$ vs. sitagliptin. Semaglutide $1.0 \mathrm{mg}: P<0.0001$ vs. sitagliptin.

$q P<0.0001$.

rSemaglutide $0.5 \mathrm{mg}$ : $P<0.0001$ vs. insulin glargine. Semaglutide $1.0 \mathrm{mg}$ : $P<0.0001$ vs. insulin glargine.

semaglutide $0.5 \mathrm{mg}$ : $P<0.0001$ vs. placebo. Semaglutide $1.0 \mathrm{mg}: P<0.0001$ vs. placebo.

tSemaglutide $0.5 \mathrm{mg}$ : $P<0.0001$ vs. dulaglutide $0.75 \mathrm{mg}$. Semaglutide $1.0 \mathrm{mg}: \mathrm{P}<0.0001 \mathrm{vs}$. dulaglutide $1.5 \mathrm{mg}$.

$B I D=$ twice daily; ER=extended release; GLP-1 RA=glucagon-like peptide-1 receptor agonist; NS=not significant; QW=twice weekly.

similar degree in AWARD-6 (-1.4\% for both drugs), but liraglutide was associated with a significantly greater reduction in body weight (-3.6 kg vs. $-2.9 \mathrm{~kg})$.

When studied as add-on therapy to a sulfonylurea (glimepiride; AWARD-8), dulaglutide $1.5 \mathrm{mg}$ produced significantly greater mean reduction in Alc from baseline to week 26 compared with placebo (-1.4\% vs. $-0.1 \%){ }^{30}$ Body weight decreased from baseline by $0.9 \mathrm{~kg}$ with dulaglutide $1.5 \mathrm{mg}$ and by $0.2 \mathrm{~kg}$ with placebo, but the difference was not statistically significant. AWARD-1 compared dulaglutide $0.75 \mathrm{mg}$ and $1.5 \mathrm{mg}$ with exenatide BID and placebo as add-on therapy to metformin and a thiazolidinedione (pioglitazone). ${ }^{24}$ Compared with both exenatide (-1.0\%) and placebo $(-0.5 \%)$, dulaglutide $0.75 \mathrm{mg}(-1.3 \%)$ and $1.5 \mathrm{mg}(-1.5 \%)$ produced significantly greater mean reductions in Alc from baseline to week 26. Body weight decreased with dulaglutide $1.5 \mathrm{mg}(-1.3 \mathrm{~kg})$ and exenatide $(-1.1 \mathrm{~kg})$ but increased slightly with dulaglutide 0.75 $\mathrm{mg}(+0.2 \mathrm{~kg})$ and placebo $(+1.2 \mathrm{~kg})$. Change in body weight was significantly different for both dulaglutide doses and exenatide compared with placebo. Compared with exenatide, dulaglutide $1.5 \mathrm{mg}$ produced a similar weight reduction, and dulaglutide $0.75 \mathrm{mg}$ produced significantly greater weight gain. When evaluated as add-on therapy to metformin plus glimepiride (AWARD-2), treatment with dulaglutide $1.5 \mathrm{mg}$ was associated 
A. Exenatide ER

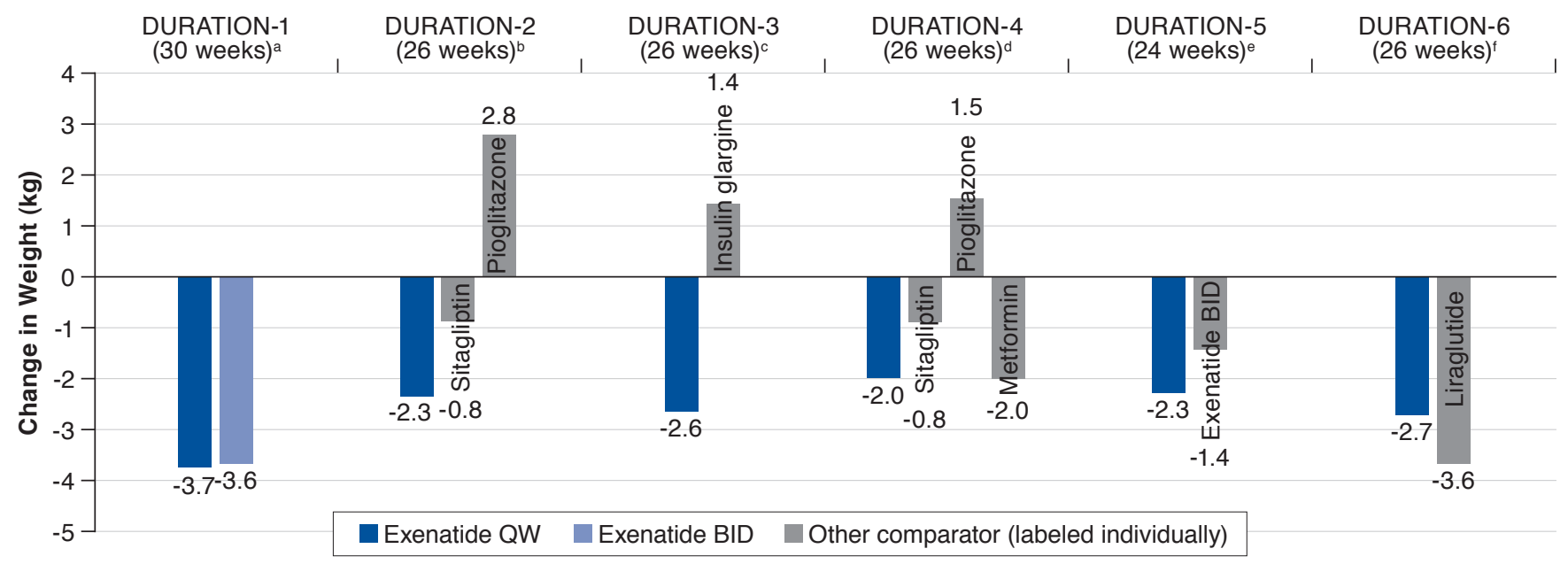

B. Dulaglutide

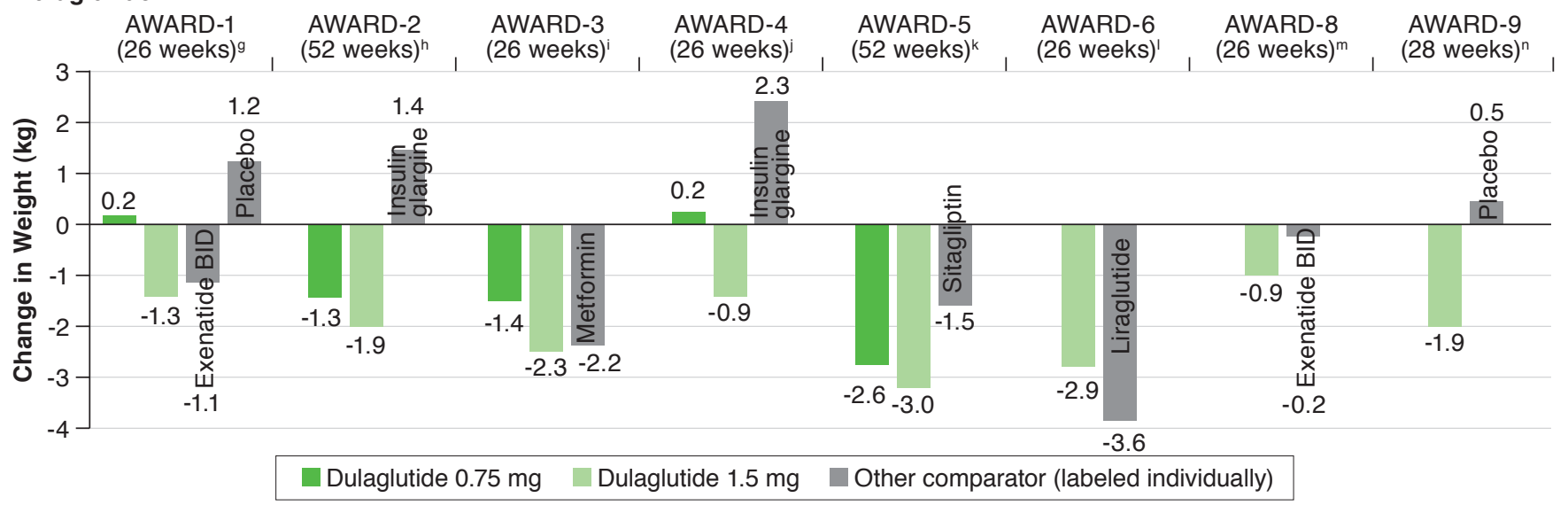

continued on next page

with significantly greater reduction from baseline to week 52 in Alc (-1.1\%) compared with insulin glargine (-0.6\%), whereas the reduction in Alc was similar between dulaglutide 0.75 mg (-0.8\%) and insulin glargine. ${ }^{25}$ Both doses of dulaglutide produced significant reductions in body weight (dulaglutide $0.75 \mathrm{mg},-1.3 \mathrm{~kg}$; dulaglutide $1.5 \mathrm{mg},-1.9 \mathrm{~kg}$; both $P<0.001 \mathrm{vs}$. insulin glargine), while insulin glargine increased body weight by $1.4 \mathrm{~kg}$ over 52 weeks.

Dulaglutide has been evaluated as add-on therapy to insulin glargine \pm metformin (AWARD-9) ${ }^{31}$ and to prandial insulin lispro \pm metformin (AWARD-4). ${ }^{27}$ In patients receiving insulin glargine \pm metformin, dulaglutide $1.5 \mathrm{mg}$ produced significantly greater improvements in Alc and body weight compared with placebo over 28 weeks of treatment (Alc: -1.4\% [dulaglutide $1.5 \mathrm{mg}$ ], -0.7\% [placebo]; body weight: $-1.9 \mathrm{~kg}$ [dulaglutide $1.5 \mathrm{mg}$ ], +0.5 kg [placebo]). ${ }^{31}$ AWARD-4 demonstrated, when used as add-on therapy to insulin lispro \pm metformin, dulaglutide $0.75 \mathrm{mg}(-1.6 \%)$ and $1.5 \mathrm{mg}(-1.6 \%)$ both produced significantly greater reductions in Alc from baseline to week 26 compared with insulin glargine (-1.4\%). ${ }^{27}$ At 26 weeks, mean body weight increased slightly with dulaglutide $0.75 \mathrm{mg}$ $(+0.2 \mathrm{~kg})$, decreased with dulaglutide $1.5 \mathrm{mg}(-0.9 \mathrm{~kg})$, and increased with insulin glargine $(+2.3 \mathrm{~kg})$. Change in body weight was significantly different with both doses of dulaglutide versus insulin glargine.

\section{Semaglutide}

SUSTAIN-1 was a placebo-controlled trial of semaglutide monotherapy. ${ }^{32}$ Compared with placebo, semaglutide $0.5 \mathrm{mg}$ and 1.0 $\mathrm{mg}$ significantly reduced both Alc (-1.5\% [semaglutide $0.5 \mathrm{mg}$ ], $-1.6 \%$ [semaglutide $1.0 \mathrm{mg}$ ], $-0.02 \%$ [placebo]) and body weight $(-3.7 \mathrm{~kg}$ [semaglutide $0.5 \mathrm{mg}$ ], $-4.5 \mathrm{~kg}$ [semaglutide $1.0 \mathrm{mg}$ ], $-1.0 \mathrm{~kg}$ 


\section{Semaglutide}

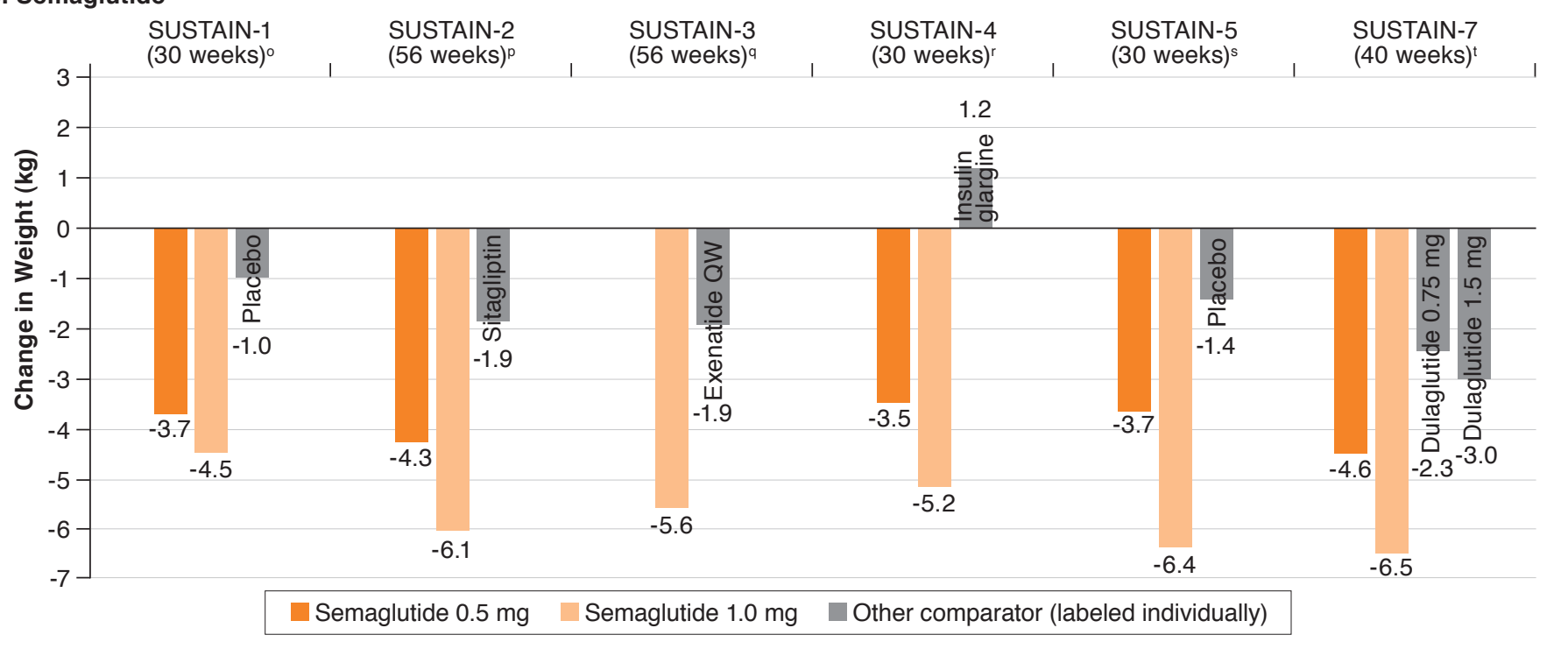

$a P=N S$.

${ }^{b} P=0.0002$ vs. sitagliptin; $P<0.0001$ vs. pioglitazone.

$c P<0.0001$.

${ }^{d} P<0.001$ vs. sitagliptin and pioglitazone; $P=N S$ vs. metformin.

e $P=N S$.

$f_{P}=0.02$

gDulaglutide $0.75 \mathrm{mg}: P<0.001$ vs. exenatide BID, $P=0.01$ vs. placebo. Dulaglutide $1.0 \mathrm{mg}$ : $P=$ NS vs. exenatide BID, $P<0.001$ vs. placebo. Exenatide BID: $P<0.001$ vs. placebo.

${ }^{h}$ Dulaglutide $0.75 \mathrm{mg}: P<0.001$ vs. insulin glargine. Dulaglutide $1.0 \mathrm{mg}: P<0.001$ vs. insulin glargine.

iDulaglutide $0.75 \mathrm{mg}: P<0.001$ vs. metformin. Dulaglutide $1.0 \mathrm{mg}: P=N S$ vs. metformin.

jDulaglutide $0.75 \mathrm{mg}: P<0.001$ vs. insulin glargine. Dulaglutide $1.0 \mathrm{mg}: P<0.001$ vs. insuline glargine.

${ }^{k}$ Dulaglutide $0.75 \mathrm{mg}: P<0.001$ vs. sitagliptin. Dulaglutide $1.0 \mathrm{mg}: P<0.001$ vs. sitagliptin.

$l_{P}=0.011$.

$m P=N S$.

${ }^{n} P<0.001$

oSemaglutide $0.5 \mathrm{mg}$ : $P<0.0001$ vs. placebo. Semaglutide $1.0 \mathrm{mg}: P<0.0001$ vs. placebo.

pSemaglutide $0.5 \mathrm{mg}$ : $P<0.0001$ vs. sitagliptin. Semaglutide $1.0 \mathrm{mg}$ : $P<0.0001$ vs. sitagliptin.

$q \mathrm{P}<0.0001$.

rSemaglutide $0.5 \mathrm{mg}: P<0.0001$ vs. insulin glargine. Semaglutide $1.0 \mathrm{mg}: P<0.0001$ vs. insulin glargine.

sSemaglutide $0.5 \mathrm{mg}: P<0.0001$ vs. placebo. Semaglutide $1.0 \mathrm{mg}: P<0.0001$ vs. placebo.

tSemaglutide $0.5 \mathrm{mg}: P<0.0001$ vs. dulaglutide $0.75 \mathrm{mg}$. Semaglutide $1.0 \mathrm{mg}: P<0.0001$ vs. dulaglutide $1.5 \mathrm{mg}$.

$B I D=$ twice daily; $E R=$ extended release; $N S=$ not signficant; $Q W=$ twice weekly.

[placebo]) from baseline to week 30. In patients receiving metformin, a thiazolidinedione, or metformin + thiazolidinedione (SUSTAIN-2), add-on therapy with semaglutide $0.5 \mathrm{mg}$ and 1.0 mg produced significantly greater reductions from baseline to 56 weeks compared with sitagliptin in both mean Alc (-1.3\% [semaglutide $0.5 \mathrm{mg}$ ], $-1.6 \%$ [semaglutide $1.0 \mathrm{mg}$ ], $-0.5 \%$ [sitagliptin]) and body weight $(-4.3 \mathrm{~kg}$ [semaglutide $0.5 \mathrm{mg}$ ], $-6.1 \mathrm{~kg}$ [semaglutide $1.0 \mathrm{mg}$ ], $-1.9 \mathrm{~kg}$ [sitagliptin]). ${ }^{33}$ When studied as add-on therapy to metformin \pm sulfonylurea (SUSTAIN-4), semaglutide $0.5 \mathrm{mg}(-1.2 \%)$ and $1.0 \mathrm{mg}(-1.6 \%)$ significantly reduced mean Alc from baseline to 30 weeks compared with insulin glargine (-0.8\%). Body weight decreased with semaglutide (-3.5 $\mathrm{kg}$ [semaglutide $0.5 \mathrm{mg}$ ], $-5.2 \mathrm{~kg}$ [semaglutide $1.0 \mathrm{mg}$ ]; both doses, $P<0.0001$ vs. insulin glargine) and increased with insulin glargine $(+1.2 \mathrm{~kg})$. SUSTAIN-3 compared semaglutide with exenatide ER as add-on therapy to 1-2 OADs and is described in greater detail below, in the section on comparative studies. ${ }^{34}$

In summary, semaglutide $1.0 \mathrm{mg}$ and exenatide ER both reduced mean Alc (-1.5\% [semaglutide $1.0 \mathrm{mg}$ ], $-0.9 \%$ [exenatide ER]) and body weight $(-5.6 \mathrm{~kg}$ [semaglutide $1.0 \mathrm{mg}$, 
-1.9 kg [exenatide ER]) from baseline to week 56, but reductions were significantly greater with semaglutide. When studied as add-on therapy to basal insulin \pm metformin (SUSTAIN-5), semaglutide $0.5 \mathrm{mg}$ and $1.0 \mathrm{mg}$ both significantly reduced Alc (-1.4\% [semaglutide $0.5 \mathrm{mg}$ ], $-1.8 \%$ [semaglutide $1.0 \mathrm{mg}$ ], $-0.1 \%$ [placebo]) and body weight (-3.7 kg [semaglutide $0.5 \mathrm{mg}$ ], -6.4 $\mathrm{kg}$ [semaglutide $1.0 \mathrm{mg}$ ], $-1.4 \mathrm{~kg}$ [placebo]) from baseline to week 30 compared with placebo. ${ }^{36}$ Semaglutide $0.5 \mathrm{mg}$ and 1.0 mg were significantly more effective than dulaglutide $0.75 \mathrm{mg}$ and $1.5 \mathrm{mg}$, respectively, with regard to Alc reductions (-1.5\% [semaglutide $0.5 \mathrm{mg}$ ], -1.8\% [semaglutide $1.0 \mathrm{mg}$ ], -1.1\% [dulaglutide $0.75 \mathrm{mg}$ ], $-1.4 \%$ [dulaglutide $1.5 \mathrm{mg}$ ]) and decreases in body weight $(-4.6 \mathrm{~kg}$ [semaglutide $0.5 \mathrm{mg}$ ], $-6.5 \mathrm{~kg}$ [semaglutide $1.0 \mathrm{mg}$ ], $-2.3 \mathrm{~kg}$ [dulaglutide $0.75 \mathrm{mg}$ ], $-3.0 \mathrm{~kg}$ [dulaglutide $1.5 \mathrm{mg}]$ ) over 40 weeks (SUSTAIN-7). ${ }^{37}$

\section{Review of Safety and Adverse Events}

As a class, GLP-1 RAs are associated with gastrointestinal side effects including nausea, vomiting, and diarrhea. ${ }^{2,38}$ Injectionsite reactions (e.g., erythema, pruritus, and nodules) may also occur in association with subcutaneous injection. Table 3 summarizes the rates of gastrointestinal side effects, injection-site reactions, and withdrawals due to adverse events (AEs) in studies of once-weekly GLP-1 RAs.

Rates of gastrointestinal AEs (nausea, vomiting, and diarrhea) observed with exenatide ER once weekly were generally similar to or lower than those reported with exenatide twice daily ${ }^{16,20}$ and tended to be higher than rates reported with OADs ${ }^{17,19}$ and insulin glargine. ${ }^{18}$ When used as add-on therapy to metformin, sulfonylurea, metformin + sulfonylurea, or metformin + thiazolidinedione, exenatide ER was associated with lower rates of gastrointestinal AEs than liraglutide. ${ }^{21}$ Rates of injection-site reactions with exenatide ER ranged from $2 \%-5 \%$ for erythema, 3\%-18\% for pruritus, and 3\%-11\% for nodules. ${ }^{16-21}$ Withdrawals due to AEs with exenatide ER once weekly ranged from 2\%-6\% and occurred at comparable rates versus exenatide twice daily, at similar or slightly higher rates compared with OADs, at a higher rate versus insulin glargine, and at a slightly lower rate compared with liraglutide.

For dulaglutide, rates of nausea, vomiting, and diarrhea tended to be dose-dependent and were generally similar to those observed with exenatide twice daily, liraglutide, and metformin and higher than rates reported with sitagliptin, insulin glargine, and placebo. ${ }^{24-28,30,31}$ Injection-site reactions with dulaglutide occurred at low rates (0\%-4\%). Rates of withdrawal due to AEs ranged from $1 \%-8 \%$ for dulaglutide $0.75 \mathrm{mg}$ and from 3\%-11\% for dulaglutide $1.5 \mathrm{mg}$; withdrawal rates due to AEs were generally similar for dulaglutide compared with exenatide twice daily, liraglutide, metformin, sitagliptin, and insulin glargine but higher than rates observed with placebo.
Similar rates of nausea, vomiting, and diarrhea were observed with semaglutide $0.5 \mathrm{mg}$ and $1.0 \mathrm{mg} .32,33,35,37$ Rates of these gastrointestinal AEs were generally higher than those reported with sitagliptin, ${ }^{33}$ insulin glargine, ${ }^{35}$ and placebo. ${ }^{32}$ Semaglutide 1.0 $\mathrm{mg}$ was associated with a lower rate of injection-site reactions than exenatide ER ( $1 \%$ vs. 22\%) in SUSTAIN-3, ${ }^{34}$ while rates were low (1-2\%) and similar to those reported with dulaglutide in SUSTAIN-7. ${ }^{37}$ Rates of withdrawal due to AEs tended to be similar to or slightly higher for semaglutide 0.5 (range, 5\%-8\%) compared with semaglutide $1.0 \mathrm{mg}$ (range, 5\%-10\%) and were generally higher with semaglutide versus sitagliptin, insulin glargine, and placebo $0^{32,33,35}$; in SUSTAIN-3 and SUSTAIN-7, the rates of discontinuation due to AEs was slightly higher with semaglutide compared with exenatide ER (9\% vs. $7 \%)^{34}$ and dulaglutide ( $8 \%-10 \%$ vs. $5 \%-7 \%$ ). ${ }^{37}$

\section{Hypoglycemia}

One advantage of GLP-1 RAs is that they tend to be associated with relatively low rates of hypoglycemia, especially serious, clinically significant hypoglycemia, defined by the American Diabetes Association (ADA) as a glucose level $<54 \mathrm{mg} / \mathrm{dL}$ (3.0 mmol/L). ${ }^{2}$ As shown in Table 3, once-weekly GLP-1 RAs are associated with very low rates of major/severe hypoglycemia. Background sulfonylurea or insulin use appears to be associated with higher rates of minor and total hypoglycemia. In clinical studies, rates of minor hypoglycemia with exenatide ER once weekly were generally similar to those observed with exenatide twice daily, ${ }^{16,20}$ liraglutide,,$^{21}$ and $\mathrm{OADs}^{17,19}$ and lower than the rate reported with insulin glargine. ${ }^{18}$

There was no clear dose-response relationship with regard to rates of minor hypoglycemia with dulaglutide. Among patients not receiving sulfonylureas or insulin, rates of minor hypoglycemia in dulaglutide-treated patients were comparable to those observed in patients receiving metformin or sitagliptin and were slightly higher in daily liraglutide-treated patients. $24,26,28,29$ Rates of minor hypoglycemia among patients with background sulfonylurea therapy were lower in dulaglutide-treated patients than in those receiving insulin glargine but higher than in placebo-treated patients..$^{25,30}$ However, rates of total hypoglycemia were comparable between patients receiving dulaglutide versus insulin glargine as add-on therapy to prandial insulin \pm metformin. ${ }^{27}$ Among patients receiving background therapy with basal insulin \pm metformin, the rate of minor hypoglycemia observed with dulaglutide was comparable to placebo levels. ${ }^{31}$

Rates of minor or total hypoglycemia were similar among patients treated with semaglutide 0.5 and $1.0 \mathrm{mg}^{32,33,35-37} \mathrm{In}$ the absence of background sulfonylurea or insulin therapy, rates of minor or total hypoglycemia associated with semaglutide treatment were very low $(0 \%-2 \%)$ and were comparable to those observed with sitagliptin, insulin glargine, or placebo. ${ }^{32,33,35}$ Among patients receiving background treatment with a sulfonylurea (including those receiving metformin, a 


\section{TABLE 3 Summary of Selected Safety, Tolerability, and Hypoglycemia Outcomes with Once-Weekly} GLP-1 RAs

\begin{tabular}{|c|c|c|c|c|c|c|c|c|}
\hline \multirow[b]{2}{*}{$\begin{array}{l}\text { Study/Background } \\
\text { Pharmacotherapy }\end{array}$} & \multirow[b]{2}{*}{ Active Comparators } & \multicolumn{5}{|c|}{ Adverse Events } & \multicolumn{2}{|c|}{ Hypoglycemia } \\
\hline & & Nausea & Vomiting & Diarrhea & $\begin{array}{l}\text { Injection-Site } \\
\text { Reactions }\end{array}$ & $\begin{array}{l}\text { Withdrawal } \\
\text { Due to AEs }\end{array}$ & $\begin{array}{c}\text { Minor } \\
\text { Hypoglycemia } \\
\end{array}$ & $\begin{array}{c}\text { Major } \\
\text { Hypoglycemia } \\
\end{array}$ \\
\hline \multicolumn{9}{|l|}{ Exenatide ER } \\
\hline \multirow{2}{*}{$\begin{array}{l}\text { DURATION-1/ } \\
\text { metformin, a sulfonylurea, } \\
\text { a TZD, or } 2 \text { OADs }^{16}\end{array}$} & $\begin{array}{l}\text { Exenatide ER } 2 \mathrm{mg} \\
\text { QW }(\mathrm{n}=148)\end{array}$ & $26 \%$ & $11 \%$ & $14 \%$ & $\begin{array}{l}\text { Pruritus: } 18 \% \\
\text { Bruising: } 5 \%\end{array}$ & $6 \%$ & $\begin{array}{l}\text { SU use: } 15 \% \\
\text { No SU use: } 0 \%\end{array}$ & $\begin{array}{l}\text { SU use: } 0 \% \\
\text { No SU use: } 0 \%\end{array}$ \\
\hline & $\begin{array}{l}\text { Exenatide } 10 \mu \mathrm{g} \\
\operatorname{BID}(\mathrm{n}=147)\end{array}$ & $35 \%$ & $19 \%$ & $13 \%$ & $\begin{array}{l}\text { Pruritus: } 1 \% \\
\text { Bruising: } 10 \%\end{array}$ & $5 \%$ & $\begin{array}{c}\text { SU use: } 15 \% \\
\text { No SU use: } 1 \% \\
\end{array}$ & $\begin{array}{c}\text { SU use: } 0 \% \\
\text { No SU use: } 0 \%\end{array}$ \\
\hline \multirow[t]{3}{*}{$\begin{array}{l}\text { DURATION-2/ } \\
\text { metformin }{ }^{17}\end{array}$} & $\begin{array}{l}\text { Exenatide ER } 2 \mathrm{mg} \\
\text { QW }(\mathrm{n}=160)\end{array}$ & $24 \%$ & $11 \%$ & $18 \%$ & Pruritus: 5\% & $6 \%$ & $1 \%$ & $0 \%$ \\
\hline & \begin{tabular}{|l|} 
Sitagliptin $100 \mathrm{mg}$ \\
QD ( $\mathrm{n}=166)$
\end{tabular} & $10 \%$ & $2 \%$ & $10 \%$ & Pruritus: 5\% & $3 \%$ & $3 \%$ & $0 \%$ \\
\hline & $\begin{array}{l}\text { Pioglitazone } 45 \mathrm{mg} \\
\text { QD (n=165) }\end{array}$ & $5 \%$ & $3 \%$ & $7 \%$ & Pruritus: $1 \%$ & $4 \%$ & $1 \%$ & $0 \%$ \\
\hline \multirow{2}{*}{$\begin{array}{l}\text { DURATION-3/ } \\
\text { metformin } \pm \\
\text { sulfonylurea }^{18}\end{array}$} & $\begin{array}{l}\text { Exenatide ER } 2 \mathrm{mg} \\
\text { QW (n=233) }\end{array}$ & $13 \%$ & $4 \%$ & $9 \%$ & $13 \%$ & $5 \%$ & $8 \%$ & $0 \%$ \\
\hline & $\begin{array}{l}\text { Insulin glargine SC } \\
(\mathrm{n}=223)\end{array}$ & $1 \%$ & $1 \%$ & $4 \%$ & $2 \%$ & $1 \%$ & $26 \%$ & $0 \%$ \\
\hline \multirow[t]{4}{*}{ DURATION-4/none ${ }^{19}$} & $\begin{array}{l}\text { Exenatide ER } 2 \mathrm{mg} \\
\mathrm{QW}(\mathrm{n}=248)\end{array}$ & $11 \%$ & $5 \%$ & $11 \%$ & Nodule: $11 \%$ & $2 \%$ & $2 \%$ & $0 \%$ \\
\hline & $\begin{array}{l}\text { Metformin 2,000 mg/d } \\
(\mathrm{n}=246)\end{array}$ & $7 \%$ & $3 \%$ & $13 \%$ & Nodule: $10 \%$ & $2 \%$ & $0 \%$ & $0 \%$ \\
\hline & $\begin{array}{l}\text { Pioglitazone } 45 \mathrm{mg} / \mathrm{d} \\
(\mathrm{n}=163)\end{array}$ & $4 \%$ & $3 \%$ & $4 \%$ & Nodule: $4 \%$ & $3 \%$ & $0 \%$ & $0 \%$ \\
\hline & $\begin{array}{l}\text { Sitagliptin } 100 \mathrm{mg} / \mathrm{d} \\
(\mathrm{n}=163)\end{array}$ & $4 \%$ & $2 \%$ & $6 \%$ & Nodule: $7 \%$ & $1 \%$ & $0 \%$ & $0 \%$ \\
\hline \multirow{2}{*}{$\begin{array}{l}\text { DURATION-5/ } \\
\text { metformin, sulfonylurea, } \\
\text { TZD, or combination } 20\end{array}$} & $\begin{array}{l}\text { Exenatide ER } 2 \mathrm{mg} \\
\mathrm{QW}(\mathrm{n}=129)\end{array}$ & $14 \%$ & $5 \%$ & $9 \%$ & Erythema: $5 \%$ & $5 \%$ & $\begin{array}{c}\text { SU use: } 13 \% \\
\text { No SU use: } 0 \%\end{array}$ & $\begin{array}{c}\text { SU use: } 0 \% \\
\text { No SU use: } 0 \%\end{array}$ \\
\hline & $\begin{array}{l}\text { Exenatide } 10 \mu \mathrm{g} \\
\mathrm{BID}(\mathrm{n}=123)\end{array}$ & $35 \%$ & $9 \%$ & $4 \%$ & Erythema: $2 \%$ & $5 \%$ & $\begin{array}{c}\text { SU use: } 12 \% \\
\text { No SU use: } 0 \% \\
\end{array}$ & $\begin{array}{c}\text { SU use: } 0 \% \\
\text { No SU use: } 0 \% \\
\end{array}$ \\
\hline \multirow{2}{*}{$\begin{array}{l}\text { DURATION-6/ } \\
\text { metformin, } \\
\text { sulfonylurea, or } \\
\text { metformin + sulfonylurea } \\
\text { or TZD } 21\end{array}$} & $\begin{array}{l}\text { Exenatide ER } 2 \mathrm{mg} \\
\text { QW }(\mathrm{n}=461)\end{array}$ & $9 \%$ & $4 \%$ & $6 \%$ & $\begin{array}{c}\text { Pruritus: } 3 \% \\
\text { Erythema: } 2 \% \\
\text { Nodule: } 3 \% \\
\end{array}$ & $3 \%$ & $\begin{array}{c}\text { SU use: } 15 \% \\
\text { No SU use: } 4 \%\end{array}$ & $\begin{array}{l}\text { SU use: } 0 \% \\
\text { No SU use: } 0 \%\end{array}$ \\
\hline & $\begin{array}{l}\text { Liraglutide } 1.8 \mathrm{mg} \\
\text { QD }(\mathrm{n}=450)\end{array}$ & $21 \%$ & $11 \%$ & $13 \%$ & $\begin{array}{c}\text { Pruritus: }<1 \% \\
\text { Erythema: }<1 \% \\
\text { Nodule: } 0 \% \\
\end{array}$ & $5 \%$ & $\begin{array}{c}\text { SU use: } 12 \% \\
\text { No SU use: } 3 \%\end{array}$ & $\begin{array}{c}\text { SU use: } 0 \% \\
\text { No SU use: } 0 \%\end{array}$ \\
\hline \multirow[t]{2}{*}{ DURATION-722 } & $\begin{array}{l}\text { Exenatide ER SC } 2 \mathrm{mg} \\
\mathrm{QW}+\text { insulin glargine } \\
(\mathrm{n}=232)\end{array}$ & \multicolumn{3}{|c|}{$\begin{array}{l}\text { Any gastrointestinal adverse event: } \\
15.1 \%\end{array}$} & $7.8 \%$ & $4 \%$ & $5.6 \%$ & $0 \%$ \\
\hline & $\begin{array}{l}\text { Placebo + insulin glargine } \\
(\mathrm{n}=231)\end{array}$ & \multicolumn{3}{|c|}{$\begin{array}{c}\text { Any gastrointestinal adverse event: } \\
10.8 \%\end{array}$} & $3.0 \%$ & $2 \%$ & $5.6 \%$ & $0 \%$ \\
\hline \multirow[t]{3}{*}{$\begin{array}{l}\text { DURATION-8/ } \\
\text { metformin } 23\end{array}$} & $\begin{array}{l}\text { Exenatide } 2 \mathrm{mg} \\
\text { QW }(\mathrm{n}=230) \\
\end{array}$ & $7 \%$ & $\mathrm{NA}$ & $6 \%$ & $\begin{array}{l}\text { Injection-site } \\
\text { events: } 12 \%\end{array}$ & $5 \%$ & Mild: $1 \%$ & $\begin{array}{c}\text { Moderate/severe: } \\
0 \%\end{array}$ \\
\hline & $\begin{array}{l}\text { Dapagliflozin } 10 \mathrm{mg} \\
\text { QD ( } \mathrm{n}=233)\end{array}$ & $3 \%$ & NA & $3 \%$ & $\begin{array}{l}\text { Injection-site } \\
\text { events: } 7 \%\end{array}$ & $2 \%$ & Mild: 1\% & $\begin{array}{c}\text { Moderate/severe: } \\
1 \%\end{array}$ \\
\hline & $\begin{array}{l}\text { Exenatide } 2 \mathrm{mg} \\
\text { QW + dapagliflozin } 10 \mathrm{mg} \\
\text { QD (n=231) } \\
\end{array}$ & $5 \%$ & $\mathrm{NA}$ & $4 \%$ & $\begin{array}{l}\text { Injection-site } \\
\text { events: } 12 \%\end{array}$ & $4 \%$ & Mild: $3 \%$ & $\begin{array}{c}\text { Moderate/severe: } \\
<1 \%\end{array}$ \\
\hline \multicolumn{9}{|l|}{ Dulaglutide } \\
\hline \multirow[t]{4}{*}{$\begin{array}{l}\text { AWARD-1/metformin + } \\
\text { TZD24 }\end{array}$} & $\begin{array}{l}\text { Dulaglutide } 0.75 \mathrm{mg} \\
\text { QW }(\mathrm{n}=280)\end{array}$ & $16 \%$ & $6 \%$ & $8 \%$ & NR & $1 \%$ & $11 \%$ & $0 \%$ \\
\hline & $\begin{array}{l}\text { Dulaglutide } 1.5 \mathrm{mg} \\
\text { QW ( } \mathrm{n}=279)\end{array}$ & $28 \%$ & $17 \%$ & $11 \%$ & NR & $3 \%$ & $10 \%$ & $0 \%$ \\
\hline & $\begin{array}{l}\text { Exenatide } 10 \mu \mathrm{g} \text { BID for } \\
(\mathrm{n}=276)\end{array}$ & $26 \%$ & $11 \%$ & $6 \%$ & NR & $3 \%$ & $\begin{array}{c}\text { Total hypo- } \\
\text { glycemia: } 16 \%\end{array}$ & $1 \%$ \\
\hline & Placebo $(n=141)$ & $6 \%$ & $1 \%$ & $6 \%$ & NR & $2 \%$ & $4 \%$ & $0 \%$ \\
\hline
\end{tabular}




\section{TABLE 3 Summary of Selected Safety, Tolerability, and Hypoglycemia Outcomes with Once-Weekly} GLP-1 RAs (continued)

\begin{tabular}{|c|c|c|c|c|c|c|c|c|}
\hline \multirow[b]{2}{*}{$\begin{array}{l}\text { Study/Background } \\
\text { Pharmacotherapy }\end{array}$} & \multirow[b]{2}{*}{ Active Comparators } & \multicolumn{5}{|c|}{ Adverse Events } & \multicolumn{2}{|c|}{ Hypoglycemia } \\
\hline & & Nausea & Vomiting & Diarrhea & $\begin{array}{l}\text { Injection-Site } \\
\text { Reactions }\end{array}$ & $\begin{array}{l}\text { Withdrawal } \\
\text { Due to AEs }\end{array}$ & $\begin{array}{c}\text { Minor } \\
\text { Hypoglycemia }\end{array}$ & $\begin{array}{c}\text { Major } \\
\text { Hypoglycemia }\end{array}$ \\
\hline \multicolumn{9}{|l|}{ Dulaglutide } \\
\hline \multirow[t]{3}{*}{$\begin{array}{l}\text { AWARD-2/ } \\
\text { metformin + sulfonylurea } 25\end{array}$} & $\begin{array}{l}\text { Dulaglutide } 0.75 \mathrm{mg} \\
\text { QW }(\mathrm{n}=272)\end{array}$ & $7 \%$ & $3 \%$ & $9 \%$ & $1 \%$ & $3 \%$ & $\begin{array}{l}\text { Total hypo- } \\
\text { glycemia: } 54 \%\end{array}$ & $0 \%$ \\
\hline & $\begin{array}{l}\text { Dulaglutide } 1.5 \mathrm{mg} \\
\text { QW }(\mathrm{n}=273)\end{array}$ & $14 \%$ & $6 \%$ & $11 \%$ & $1 \%$ & $3 \%$ & $\begin{array}{l}\text { Total hypo- } \\
\text { glycemia: } 55 \%\end{array}$ & $<1 \%$ \\
\hline & $\begin{array}{l}\text { Insulin glargine } \\
(\mathrm{n}=262)\end{array}$ & $2 \%$ & $1 \%$ & $4 \%$ & $0 \%$ & $2 \%$ & $\begin{array}{l}\text { Total hypo- } \\
\text { glycemia: } 69 \%\end{array}$ & $1 \%$ \\
\hline \multirow[t]{3}{*}{ AWARD-3/none 26} & $\begin{array}{l}\text { Dulaglutide } 0.75 \mathrm{mg} \\
\text { QW }(\mathrm{n}=270)\end{array}$ & $11 \%$ & $6 \%$ & $5 \%$ & $2 \%$ & $2 \%$ & $11 \%$ & $0 \%$ \\
\hline & $\begin{array}{l}\text { Dulaglutide } 1.5 \mathrm{mg} \\
\text { QW }(\mathrm{n}=269)\end{array}$ & $19 \%$ & $9 \%$ & $10 \%$ & $4 \%$ & $5 \%$ & $12 \%$ & $0 \%$ \\
\hline & $\begin{array}{l}\text { Metformin } 2,000 \mathrm{mg} / \mathrm{d} \\
(\mathrm{n}=268)\end{array}$ & $15 \%$ & $4 \%$ & $14 \%$ & $\begin{array}{l}2 \% \text { (placebo } \\
\text { injections) }\end{array}$ & $4 \%$ & $13 \%$ & $0 \%$ \\
\hline \multirow[t]{3}{*}{$\begin{array}{l}\text { AWARD-4/prandial } \\
\text { insulin } \pm \text { metformin }{ }^{\mathrm{a}, 27}\end{array}$} & $\begin{array}{l}\text { Dulaglutide } 0.75 \mathrm{mg} \\
\text { QW }(\mathrm{n}=293)\end{array}$ & $18 \%$ & $11 \%$ & $16 \%$ & $1 \%$ & $5 \%$ & $\begin{array}{c}\text { Total hypo- } \\
\text { glycemia: } \\
\text { PG } \leq 3.9 \mathrm{mmol} / \mathrm{L}: \\
90 \% \\
\mathrm{PG}<3.0 \mathrm{mmol} / \mathrm{L}: \\
79 \%\end{array}$ & $3 \%$ \\
\hline & $\begin{array}{l}\text { Dulaglutide } 1.5 \mathrm{mg} \\
\text { QW }(\mathrm{n}=295)\end{array}$ & $26 \%$ & $12 \%$ & $17 \%$ & $<1 \%$ & $7 \%$ & $\begin{array}{c}\text { Total hypo- } \\
\text { glycemia: } \\
\text { PG } \leq 3.9 \mathrm{mmol} / \mathrm{L}: \\
87 \% \\
\mathrm{PG}<3.0 \mathrm{mmol} / \mathrm{L}: \\
72 \%\end{array}$ & $3 \%$ \\
\hline & $\begin{array}{l}\text { Insulin glargine } \\
(\mathrm{n}=296)\end{array}$ & $3 \%$ & $2 \%$ & $6 \%$ & $0 \%$ & $4 \%$ & $\begin{array}{c}\text { Total hypo- } \\
\text { glycemia: } \\
\text { PG } \leq 3.9 \mathrm{mmol} / \mathrm{L}: \\
90 \% \\
\mathrm{PG}<3.0 \mathrm{mmol} / \mathrm{L}: \\
74 \%\end{array}$ & $5 \%$ \\
\hline \multirow[t]{3}{*}{ AWARD-5/metformin 28} & $\begin{array}{l}\text { Dulaglutide } 0.75 \mathrm{mg} \\
\text { QW }(\mathrm{n}=302)\end{array}$ & $14 \%$ & $8 \%$ & $10 \%$ & "rare" & $8 \%$ & $5 \%$ & $0 \%$ \\
\hline & $\begin{array}{l}\text { Dulaglutide } 1.5 \mathrm{mg} \\
\text { QW }(\mathrm{n}=304)\end{array}$ & $17 \%$ & $13 \%$ & $15 \%$ & "rare" & $11 \%$ & $10 \%$ & $0 \%$ \\
\hline & $\begin{array}{l}\text { Sitagliptin } 100 \mathrm{mg} \\
\mathrm{QD}(\mathrm{n}=315)\end{array}$ & $5 \%$ & $2 \%$ & $3 \%$ & "rare" & $10 \%$ & $5 \%$ & $0 \%$ \\
\hline \multirow[t]{2}{*}{ AWARD-6/metformin 29} & $\begin{array}{l}\text { Dulaglutide SC } 1.5 \mathrm{mg} \\
\text { QW }(\mathrm{n}=299)\end{array}$ & $20 \%$ & $7 \%$ & $12 \%$ & $<1 \%$ & $6 \%$ & $9 \%$ & $0 \%$ \\
\hline & $\begin{array}{l}\text { Liraglutide } 1.8 \mathrm{mg} \\
\mathrm{QD}(\mathrm{n}=300)\end{array}$ & $18 \%$ & $8 \%$ & $12 \%$ & $1 \%$ & $6 \%$ & $6 \%$ & $0 \%$ \\
\hline \multirow[t]{2}{*}{ AWARD-8/sulfonylurea30 } & $\begin{array}{l}\text { Dulaglutide } 1.5 \mathrm{mg} \\
\text { QW }(\mathrm{n}=239)\end{array}$ & $11 \%$ & $4 \%$ & $8 \%$ & $0 \%$ & $4 \%$ & $21 \%$ & $0 \%$ \\
\hline & Placebo $(n=60)$ & $0 \%$ & $0 \%$ & $0 \%$ & $0 \%$ & $0 \%$ & $3 \%$ & $0 \%$ \\
\hline \multirow[t]{2}{*}{$\begin{array}{l}\text { AWARD-9/basal } \\
\text { insulin } \pm \text { metformin } 31\end{array}$} & $\begin{array}{l}\text { Dulaglutide } 1.5 \mathrm{mg} \\
\text { QW }(\mathrm{n}=150)\end{array}$ & $12 \%$ & $6 \%$ & $11 \%$ & $1 \%$ & $4 \%$ & $\begin{array}{c}\text { Total hypo- } \\
\text { glycemia: } 55 \%\end{array}$ & $1 \%$ \\
\hline & Placebo $(n=150)$ & $1 \%$ & $0 \%$ & $4 \%$ & $0 \%$ & $1 \%$ & $51 \%$ & $0 \%$ \\
\hline \multicolumn{9}{|l|}{ Semaglutide } \\
\hline \multirow[t]{3}{*}{ SUSTAIN-1/none 32} & $\begin{array}{l}\text { Semaglutide } 0.5 \mathrm{mg} \\
\mathrm{QW}(\mathrm{n}=128)\end{array}$ & $20 \%$ & $4 \%$ & $13 \%$ & NR & $6 \%$ & $0 \%$ & $0 \%$ \\
\hline & $\begin{array}{l}\text { Semaglutide } 1.0 \mathrm{mg} \\
\mathrm{QW}(\mathrm{n}=130)\end{array}$ & $24 \%$ & $7 \%$ & $11 \%$ & NR & $5 \%$ & $0 \%$ & $0 \%$ \\
\hline & Placebo $(n=129)$ & $8 \%$ & $2 \%$ & $2 \%$ & NR & $2 \%$ & \multicolumn{2}{|c|}{$\begin{array}{l}\text { Total hypoglycemia: } 2 \% \\
\text { (3 events, } 2 \text { patients after } \\
\text { receiving rescue medication) }\end{array}$} \\
\hline
\end{tabular}


TABLE 3 Summary of Selected Safety, Tolerability, and Hypoglycemia Outcomes with Once-Weekly GLP-1 RAs (continued)

\begin{tabular}{|c|c|c|c|c|c|c|c|c|}
\hline \multirow[b]{2}{*}{$\begin{array}{l}\text { Study/Background } \\
\text { Pharmacotherapy }\end{array}$} & \multirow[b]{2}{*}{ Active Comparators } & \multicolumn{5}{|c|}{ Adverse Events } & \multicolumn{2}{|c|}{ Hypoglycemia } \\
\hline & & Nausea & Vomiting & Diarrhea & $\begin{array}{l}\text { Injection-Site } \\
\text { Reactions }\end{array}$ & $\begin{array}{l}\text { Withdrawal } \\
\text { Due to AEs }\end{array}$ & \begin{tabular}{|c|} 
Minor \\
Hypoglycemia
\end{tabular} & $\begin{array}{c}\text { Major } \\
\text { Hypoglycemia }\end{array}$ \\
\hline \multirow{3}{*}{$\begin{array}{l}\text { SUSTAIN-2/metformin, } \\
\text { TZD, or metformin + } \\
\text { TZD } 33\end{array}$} & $\begin{array}{l}\text { Semaglutide } 0.5 \mathrm{mg} \\
\text { QW }(\mathrm{n}=409)\end{array}$ & $18 \%$ & $8 \%$ & $13 \%$ & NR & $8 \%$ & $2 \%$ & $0 \%$ \\
\hline & $\begin{array}{l}\text { Semaglutide } 1.0 \mathrm{mg} \\
\text { QW }(\mathrm{n}=409)\end{array}$ & $18 \%$ & $10 \%$ & $13 \%$ & NR & $10 \%$ & $<1 \%$ & $0 \%$ \\
\hline & $\begin{array}{l}\text { Sitagliptin } 100 \mathrm{mg} \\
\mathrm{QD}(\mathrm{n}=407)\end{array}$ & $7 \%$ & $3 \%$ & $7 \%$ & NR & $3 \%$ & $1 \%$ & $<1 \%$ \\
\hline \multicolumn{9}{|l|}{ Semaglutide } \\
\hline \multirow{2}{*}{$\begin{array}{l}\text { SUSTAIN-3/1-2 OADs } \\
\text { (metformin, sulfonylurea, } \\
\text { or TZD) }^{34}\end{array}$} & $\begin{array}{l}\text { Semaglutide } 1.0 \mathrm{mg} \\
\text { QW }(\mathrm{n}=404)\end{array}$ & $22 \%$ & $7 \%$ & $11 \%$ & $1 \%$ & $9 \%$ & \multicolumn{2}{|c|}{ Total hypoglycemia: $8 \%$} \\
\hline & $\begin{array}{l}\text { Exenatide ER } 2.0 \mathrm{mg} \\
\text { QW }(\mathrm{n}=405)\end{array}$ & $12 \%$ & $6 \%$ & $8 \%$ & $22 \%$ & $7 \%$ & \multicolumn{2}{|c|}{ Total hypoglycemia: 8\% } \\
\hline \multirow[t]{3}{*}{$\begin{array}{l}\text { SUSTAIN-4/metformin } \pm \\
\text { sulfonylurea }\end{array}$} & $\begin{array}{l}\text { Semaglutide } 0.5 \mathrm{mg} \\
\text { QW }(\mathrm{n}=362)\end{array}$ & $21 \%$ & $7 \%$ & $16 \%$ & NR & $6 \%$ & \begin{tabular}{|c|} 
Total hypo- \\
glycemia: SU \\
use: $8 \%$ \\
No SU use: $<1 \%$ \\
\end{tabular} & $<1 \%$ \\
\hline & $\begin{array}{l}\text { Semaglutide } 1.0 \mathrm{mg} \\
\text { QW }(\mathrm{n}=360)\end{array}$ & $22 \%$ & $10 \%$ & $19 \%$ & NR & $8 \%$ & $\begin{array}{c}\text { Total hypo- } \\
\text { glycemia: SU } \\
\text { use: } 9 \% \\
\text { No SU use: } 2 \% \\
\end{array}$ & $1 \%$ \\
\hline & $\begin{array}{l}\text { Insulin glargine } \\
(\mathrm{n}=360)\end{array}$ & $4 \%$ & $3 \%$ & $4 \%$ & NR & $1 \%$ & \begin{tabular}{|c|} 
Total hypo- \\
glycemia: SU \\
use: $18 \%$ \\
No SU use: $2 \%$ \\
\end{tabular} & $1 \%$ \\
\hline \multirow[t]{3}{*}{$\begin{array}{l}\text { SUSTAIN-5/basal } \\
\text { insulin } \pm \text { metformin } 36\end{array}$} & $\begin{array}{l}\text { Semaglutide } 0.5 \mathrm{mg} \\
\text { QW }(\mathrm{n}=132)\end{array}$ & $11 \%$ & $6 \%$ & $5 \%$ & NA & $5 \%$ & \multicolumn{2}{|c|}{ Total hypoglycemia: $8 \%$} \\
\hline & $\begin{array}{l}\text { Semaglutide } 1.0 \mathrm{mg} \\
\text { QW }(\mathrm{n}=131)\end{array}$ & $17 \%$ & $12 \%$ & $7 \%$ & NA & $6 \%$ & \multicolumn{2}{|c|}{ Total hypoglycemia: 11\% } \\
\hline & Placebo $(n=133)$ & $5 \%$ & $3 \%$ & $2 \%$ & NA & $1 \%$ & \multicolumn{2}{|c|}{ Total hypoglycemia: 5\% } \\
\hline \multirow[t]{4}{*}{ SUSTAIN-737 } & $\begin{array}{l}\text { Semaglutide } 0.5 \mathrm{mg} \\
\mathrm{QW}(\mathrm{n}=301)\end{array}$ & $23 \%$ & $10 \%$ & $14 \%$ & $1 \%$ & $8 \%$ & \multicolumn{2}{|c|}{$\begin{array}{c}\text { Severe or blood glucose-confirmed } \\
\text { hypoglycemia: } 1 \%\end{array}$} \\
\hline & $\begin{array}{l}\text { Semaglutide } 1.0 \mathrm{mg} \\
\text { QW }(\mathrm{n}=300)\end{array}$ & $21 \%$ & $10 \%$ & $14 \%$ & $2 \%$ & $10 \%$ & \multicolumn{2}{|c|}{$\begin{array}{c}\text { Severe or blood glucose-confirmed } \\
\text { hypoglycemia: } 2 \%\end{array}$} \\
\hline & $\begin{array}{l}\text { Dulaglutide } 0.75 \mathrm{mg} \\
(\mathrm{n}=299)\end{array}$ & $13 \%$ & $4 \%$ & $8 \%$ & $1 \%$ & $5 \%$ & \multicolumn{2}{|c|}{$\begin{array}{c}\text { Severe or blood glucose-confirmed } \\
\text { hypoglycemia: } 1 \%\end{array}$} \\
\hline & $\begin{array}{l}\text { Dulaglutide } 1.5 \mathrm{mg} \\
(\mathrm{n}=299)\end{array}$ & $20 \%$ & $10 \%$ & $18 \%$ & $3 \%$ & $7 \%$ & \multicolumn{2}{|c|}{$\begin{array}{c}\text { Severe or blood glucose-confirmed } \\
\text { hypoglycemia: } 2 \%\end{array}$} \\
\hline
\end{tabular}

Note: Percentages based on numbers for safety analyses, which sometimes differed from numbers of randomized patients. Unless otherwise indicated, data represent timepoint defined by primary endpoints.

aPrimary efficacy endpoint for AWARD-4 was 26 weeks, but study only reported safety data for 52 weeks.

$A E=$ adverse event $; B I D=$ twice daily; $E R=$ extended release $; G L P-1$ RA = glucagon-like peptide-1 receptor agonist NA =not available $;$ NR =not reported; OAD=oral antihyperglycemic drug; $P G=$ plasma glucose; $Q D=$ once daily; $Q W=$ once weekly; $S U=$ sulfonylurea; TZD=thiazolidinedione.

sulfonylurea, or a thiazolidinedione in one study), rates of total hypoglycemia were similar among semaglutide, exenatide ER, and dulaglutide and were higher with insulin glargine. ${ }^{34,35,37}$ Compared with placebo, semaglutide as add-on therapy to basal insulin + metformin was associated with higher rates of total hypoglycemia. ${ }^{36}$

\section{Comparative Studies of Once-Weekly GLP-1 RAs}

\section{Head-to-Head Studies}

SUSTAIN-3 was a randomized, open-label, multicenter, 56 -week trial comparing semaglutide $1.0 \mathrm{mg}$ versus $2.0 \mathrm{mg}$ exenatide ER as add-on treatment to 1 or 2 OADs in 813 patients with T2DM. ${ }^{34}$ The overall baseline mean Alc was $8.3 \%$. As previously described (Figure $1 \mathrm{C}$ ), the change from baseline to week 56 in Alc was significantly greater with semaglutide $1.0 \mathrm{mg}$ compared with exenatide ER $2.0 \mathrm{mg}(-1.5 \%$ vs. $-0.9 \%$; treatment difference, $-0.62 \% ; P<0.0001)$. Greater proportions of semaglutide- versus exenatide-treated patients achieved Alc $\leq 7.0 \%$ (67\% vs. $40 \%$ ) and Alc $\leq 6.5 \%$ (47\% vs, $22 \% ; P<0.0001$ ). Compared with exenatide, semaglutide produced a significantly greater reduction in mean body weight ( $-5.6 \mathrm{~kg}$ vs. $-1.9 \mathrm{~kg}$; treatment difference, $-3.78 \mathrm{~kg}$; $P<0.0001)$. 
Additionally, semaglutide was associated with significantly greater improvements compared with exenatide ER in fasting plasma glucose (-2.8 vs. $-2.0 \mathrm{mmol} / \mathrm{L}, P<0.0001)$, 7-point selfmeasured plasma glucose $(-2.2$ vs. $-1.5 \mathrm{mmol} / \mathrm{L}, P<0.0001)$, postprandial increment in plasma glucose across all meals (-0.6 vs. $-0.3 \mathrm{mmol} / \mathrm{L}, P=0.0189)$, systolic blood pressure $(-4.6$ vs. $-2.2 \mathrm{mmHg}, P=0.0158)$, and overall treatment satisfaction (Diabetes Treatment Satisfaction Questionnaire Status Version; estimated treatment difference, 1.02; $P=0.0068$ ). Rates of AEs were comparable between treatment groups (75.0\% semaglutide, $76.3 \%$ exenatide). The most frequent AEs were gastrointestinal in nature, reported by $41.8 \%$ and $33.3 \%$ of patients in the semaglutide and exenatide ER groups, respectively. Injection-site reactions were notably less common with semaglutide (1.2\%) compared with exenatide ER (22.0\%). These results indicate that semaglutide $1.0 \mathrm{mg}$ is superior to exenatide ER $2.0 \mathrm{mg}$ with regard to improving glycemic control and reducing body weight in patients with T2DM. Semaglutide was well tolerated and showed a safety profile similar to that of exenatide ER.

A phase 3b, 40-week, efficacy and safety trial (SUSTAIN-7) compared semaglutide $0.5 \mathrm{mg}$ versus dulaglutide $0.75 \mathrm{mg}$ and semaglutide $1.0 \mathrm{mg}$ versus dulaglutide $1.5 \mathrm{mg}$ as add-on therapy to metformin in 1,201 patients with T2DM. ${ }^{37}$ The mean baseline Alc was $8.2 \%$. Reduction in Alc was statistically significantly greater with semaglutide $0.5 \mathrm{mg}$ versus dulaglutide $0.75 \mathrm{mg}$ $(-1.5 \%$ vs. $-1.1 \%)$ and with semaglutide $1.0 \mathrm{mg}$ versus dulaglutide $1.5 \mathrm{mg}$ (-1.8\% vs. $-1.4 \%)$. A treatment goal of Alc $\leq 7.0 \%$ was achieved by $68 \%$ of patients treated with semaglutide $0.5 \mathrm{mg}$ compared with $52 \%$ of those treated with dulaglutide $0.75 \mathrm{mg}$ and with $79 \%$ of patients receiving semaglutide $1.0 \mathrm{mg}$ compared with $67 \%$ of patients treated with dulaglutide $1.5 \mathrm{mg}$. Similarly, greater percentages of patients treated with semaglutide $0.5 \mathrm{mg}$ (49\%) and $1.0 \mathrm{mg}(67 \%)$ achieved Alc $\leq 6.5 \%$ compared with those receiving dulaglutide $0.75 \mathrm{mg}$ (34\%) and dulaglutide $1.0 \mathrm{mg}$ (47\%), respectively. The overall mean baseline body weight was $95 \mathrm{~kg}$. Mean weight loss was statistically significantly greater among patients treated with semaglutide $0.5 \mathrm{mg}$ versus dulaglutide $0.75 \mathrm{mg}(4.6 \mathrm{~kg}$ vs. $2.3 \mathrm{~kg})$ and among those treated with semaglutide $1.0 \mathrm{mg}$ versus dulaglutide $1.0 \mathrm{mg}(6.5 \mathrm{~kg}$ vs. $3.0 \mathrm{~kg}$ ). For both doses of semaglutide, the most common $\mathrm{AE}$ was mild to moderate nausea, which was comparable in frequency to dulaglutide and diminished over time. These findings demonstrate superior glycemic control and weight reduction with semaglutide versus dulaglutide as add-on therapy to metformin in patients with T2DM.

\section{Meta-Analyses}

Several meta-analyses have used data from controlled clinical trials to indirectly compare the effects of once-weekly GLP-1 RAs on glycemic control, weight, and safety/tolerability. ${ }^{39-41}$ As a caveat, differences in study designs and patient populations may have influenced metabolic results. Meta-analyses have not found any significant differences between exenatide ER, albiglutide, and dulaglutide with respect to improvements in Alc or body weight. ${ }^{39,41,42}$ A network meta-analysis comparing exenatide ER with other GLP-1 RAs (albiglutide, dulaglutide, exenatide, liraglutide, and lixisenatide) as add-on therapy to metformin in patients with T2DM inadequately controlled on metformin alone found that there were no statistically significant differences between exenatide ER and other GLP-1 RAs with respect to rates of nausea and rates of discontinuation due to AEs. ${ }^{39}$ In contrast, a meta-analysis of randomized controlled trials in patients with T2DM lasting between 24 and 32 weeks found that, while the risk of diarrhea was similar among once-weekly GLP-1 RAs, dulaglutide significantly increased the risk of nausea compared with exenatide ER and albiglutide and also increased the risk of vomiting compared with exenatide ER. ${ }^{42}$ The risk of hypoglycemia did not differ significantly among once-weekly GLP-1 RAs.

\section{Studies of Device Attribute Preferences}

Each once-weekly GLP-1 RA has a unique device for administration. A web-based survey of 643 U.S. patients with T2DM (184 injection-naive) found that a shorter/thinner needle was preferred over a longer/thicker needle and that eliminating injection-site reactions was considered by patients to be important. ${ }^{43}$ Injection-naive patients in the UK comparing dulaglutide versus liraglutide indicated a preference for a single-use prefilled pen versus a multidose pen. ${ }^{44} \mathrm{~A}$ multinational webbased survey in injection-naive patients found that patients preferred no titration versus titration, preferred a multi-use pen over a vial/syringe, and preferred an autoinjector over a single-use pen. ${ }^{45}$ Among injection-experienced patients from the United Kingdom and Germany who completed a webbased survey, a multi-use pen or autoinjector was preferred over a vial/syringe. ${ }^{46}$

\section{Discussion}

Over the past 5 years, several once-weekly GLP-1 RAs have been approved to treat T2DM and have been shown to be highly effective, although they are not generally recommended as first-line therapy for patients inadequately controlled on diet and exercise. ${ }^{11-14}$ In monotherapy studies, exenatide ER and dulaglutide produced similar or superior reductions in Alc and weight compared with OADs. ${ }^{19,26}$ Semaglutide demonstrated significantly greater effects on Alc and body weight compared to placebo. ${ }^{32,36}$ The efficacy of once-weekly GLP-1 RAs for reducing Alc and weight has also been demonstrated as addon therapy to a variety of background medications, including 1 or more OADs (all once-weekly GLP-1 RAs) and basal (albiglutide, dulaglutide, and semaglutide) and prandial (dulaglutide) insulin. Head-to-head comparisons of once-weekly GLP-1 RAs have demonstrated significantly greater improve- 
ments in glycemic control and body weight with semaglutide versus both exenatide ER (SUSTAIN-3) and dulaglutide (SUSTAIN-7). ${ }^{34,37}$ Considering its effects on body weight, semaglutide may be particularly appropriate for use in patients with both T2DM and obesity.

As with GLP-1 RAs as a class, the most common AEs observed with once-weekly GLP-1 RAs are gastrointestinal in nature. Observed rates of nausea and vomiting were higher with exenatide compared with exenatide ER, and rates of gastrointestinal AEs were generally greater with once-weekly GLP-1 RAs than with OADs (except perhaps metformin) and insulin (Table 3). Reported rates of hypoglycemia were generally low with once-weekly GLP-1 RAs and higher in the presence of sulfonylurea or insulin background therapy (Table 3). It is recommended to consider lowering the dose of concomitant sulfonylurea or insulin therapy to reduce the risk of hypoglycemia when used in combination with a once-weekly GLP-1 RA (Table 1).

The distinction between short-acting and long-acting GLP-1 RAs is based on their elimination half-lives, with short-acting GLP-1 RAs (exenatide and lixisenatide) having half-lives of 2-5 hours and long-acting GLP-1 RAs (once-weekly GLP-1 RAs, liraglutide) having half-lives exceeding 12 hours. ${ }^{47}$ One advantage of long-acting GLP-1 RAs is that they afford greater flexibility because timing of administration is independent of meal ingestion. Short-acting GLP-1 RAs suppress gastric emptying more so than long-acting GLP-1 RAs, resulting in greater reductions in postprandial glucose levels. ${ }^{47-49}$ In contrast, long-acting GLP-1 RAs exert their effects primarily by stimulating insulin secretion from the pancreas and produce greater reductions in fasting glucose. These differences in properties of long-acting versus short-acting GLP-1 RAs are evident in comparisons of exenatide ER versus exenatide: exenatide ER produced significantly greater reduction in fasting plasma glucose than exenatide in DURATION-1 and DURATION-5. ${ }^{16,20}$ While exenatide ER and exenatide showed similar reductions in postprandial glucose at baseline, the effect of exenatide ER was diminished by week 30 because of tachyphylaxis associated with more continuous drug exposure. ${ }^{16}$

Once-weekly GLP-1 RAs provide greater convenience and may promote better adherence relative to daily GLP-1 RAs, ${ }^{47,50,51}$ and some data suggest that once-weekly versus daily dosing is generally preferred by patients. ${ }^{43,45,46}$

\section{Conclusions}

Once-weekly GLP-1 RAs provide a safe and effective option for achieving glycemic control and weight loss in patients with T2DM and may help simplify the treatment regimen with onceweekly dosing. Given their efficacy, low risk of hypoglycemia and weight gain, and convenience, once-weekly GLP-1 RAs may play an important role in helping clinicians and patients with T2DM overcome clinical inertia and attain glycemic goals.

\section{Authors}

YEHUDA HANDELSMAN, MD, FACP, FNLA, FASPC, MACE, Metabolic Institute of America, Tarzana, California; KATHLEEN WYNE, MD, PhD, FACE, FNLA, The Ohio State University Wexner Medical Center, Columbus; ANTHONY CANNON, MD, FACE, Private Practice, Hamilton, New Jersey; MICHAEL SHANNON, MD, PMG Olympia Endocrinology, Lacey, Washington; and DORON SCHNEIDER, MD, FACP, Jefferson Health at Abington Hospital, Abington, Pennsylvania.

\section{DISCLOSURES}

This supplement was funded by Novo Nordisk. Handelsman reports research grants from Amgen, AstraZeneca, Bristol-Myers Squibb, Boehringer Ingelheim, Grifols, Janssen, Lexicon, Merck, Novo Nordisk, Regeneron, and Sanofi; speaker fees from Amarin, Amgen, AstraZeneca, Boehringer Ingelheim-Lilly, Janssen, Merck, Novo Nordisk, Regeneron, and Sanofi; and has served in advisory capacity to Amarin, Amgen, AstraZeneca, Boehringer Ingelheim, Eisai, Intarcia, Janssen, Lilly, Merck, Merck-Pfizer, Novo Nordisk, Regeneron, and Sanofi. Cannon reports speaker fees and owns stock in Novo Nordisk. Shannon reports consultant and speaker fees from Novo Nordisk and Boehringer Ingelheim-Lilly Alliance. Schneider reports advisory board fees from Intarcia, Lilly, and Novo Nordisk. Wyne has nothing to disclose.

\section{ACKNOWLEDGMENTS}

Writing assistance was provided by Adrienne Drinkwater, PhD, and Sandra Westra, PharmD, through Churchill Communications (Maplewood, NJ) and funded by Novo Nordisk.

\section{REFERENCES}

1. Lipska KJ, Yao X, Herrin J, et al. Trends in drug utilization, glycemic control, and rates of severe hypoglycemia, 2006-2013. Diabetes Care. 2017;40(4):468-75.

2. American Diabetes Association. Standards of medical care in diabetes 2018. Available at: https://professional.diabetes.org/content-page/standardsmedical-care-diabetes. Accessed July 6, 2018

3. Garber AJ, Abrahamson MJ, Barzilay JI, et al. Consensus statement by the American Association of Clinical Endocrinologists and American College of Endocrinology on the comprehensive type 2 diabetes management algorithm - 2017 executive summary. Endocr Pract. 2017;23(2):207-38

4. Strain WD, Cos X, Hirst M, et al. Time to do more: addressing clinical inertia in the management of type 2 diabetes mellitus. Diabetes Res Clin Pract. 2014;105(3):302-12.

5. Blonde L, Aschner P, Bailey C, Ji L, Leiter LA, Matthaei S; Global Partnership for Effective Diabetes Management. Gaps and barriers in the control of blood glucose in people with type 2 diabetes. Diab Vasc Dis Res. 2017;14(3):172-83

6. Lee S, Lee DY. Glucagon-like peptide-1 and glucagon-like peptide-1 receptor agonists in the treatment of type 2 diabetes. Ann Pediatr Endocrinol Metab. 2017;22(1):15-26.

7. Levin PA, Nguyen H, Wittbrodt ET, Kim SC. Glucagon-like peptide-1 receptor agonists: a systematic review of comparative effectiveness research. Diabetes Metab Syndr Obes. 2017;10:123-39.

8. Byetta (exenatide extended-release for injectable suspension). AstraZeneca Pharmaceuticals. Revised February 2015. Available at: https://www.fda.gov/ downloads/drugs/drugsafety/ucm191084.pdf. Accessed July 10, 2018. 
9. Victoza (liraglutide [rDNA origin] injection), solution for subcutaneous use. Novo Nordisk. Revised August 2017. Available at: https://www.accessdata.fda.gov/drugsatfda_docs/label/2017/022341s027lbl.pdf. Accessed July 23, 2018.

10. Adlyxin (lixisenatide) injection, for subcutaneous use. Sanofi-Aventis U.S. Revised July 2016. Available at: https://www.accessdata.fda.gov/drugsatfda_docs/nda/2016/208471Origls000lbl.pdf. Accessed July 10, 2018.

11. Bydureon (exenatide extended-release) injectable. AstraZeneca Pharmaceuticals. Revised September 2015. Available at: https://www.accessdata.fda.gov/drugsatfda_docs/label/2015/022200s020lbl.pdf. Accessed July 23, 2018.

12. Trulicity (dulaglutide) injection, for subcutaneous use. Eli Lilly and Company. Revised August 2017. Available at: https://www.accessdata.fda.gov/ drugsatfda_docs/label/2017/125469s011s013lbl.pdf. Accessed July 10, 2018.

13. Ozempic (semaglutide) injection, for subcutaneous use. Novo Nordisk. Revised December 2017. Available at: https://www.accessdata.fda.gov/drugsatfda_docs/label/2017/209637lbl.pdf. Accessed July 10, 2018.

14. Tanzeum (albiglutide) for injection, for subcutaneous use. GlaxoSmithKline. Revised August 2017. Available at: https://www.accessdata.fda.gov/drugsatfda_docs/label/2017/125431s019lbl.pdf. Accessed July 10, 2018.

15. GlaxoSmithKline. Press release. TANZEUM (albiglutide) discontinuation-Q \& A. July 26, 2017. Available at: https://www.tanzeum.com/pdfs/ consumer-faq.pdf. Accessed July 6, 2018.

16. Drucker DJ, Buse JB, Taylor K, et al. Exenatide once weekly versus twice daily for the treatment of type 2 diabetes: a randomised, open-label, noninferiority study. Lancet. 2008;372(9645):1240-50.

17. Bergenstal RM, Wysham C, Macconell L, et al.; DURATION-2 Study Group. Efficacy and safety of exenatide once weekly versus sitagliptin or pioglitazone as an adjunct to metformin for treatment of type 2 diabetes (DURATION-2): a randomised trial. Lancet. 2010;376(9739):431-39.

18. Diamant M, Van Gaal L, Stranks S, et al. Once weekly exenatide compared with insulin glargine titrated to target in patients with type 2 diabetes (DURATION-3): an open-label randomised trial. Lancet. 2010;375(9733):2234-43.

19. Russell-Jones D, Cuddihy RM, Hanefeld M, et al.; DURATION-4 Study Group. Efficacy and safety of exenatide once weekly versus metformin, pioglitazone, and sitagliptin used as monotherapy in drug-naive patients with type 2 diabetes (DURATION-4): a 26-week double-blind study. Diabetes Care. 2012;35(2):252-58

20. Blevins T, Pullman J, Malloy J, et al. DURATION-5: exenatide once weekly resulted in greater improvements in glycemic control compared with exenatide twice daily in patients with type 2 diabetes. J Clin Endocrinol Metab. 2011;96(5):1301-10.

21. Buse JB, Nauck M, Forst T, et al. Exenatide once weekly versus liraglutide once daily in patients with type 2 diabetes (DURATION-6): a randomised, open-label study. Lancet. 2013;381(9861):117-24.

22. Guja C, Frias JP, Somogyi A, et al. Effect of exenatide QW or placebo, both added to titrated insulin glargine, in uncontrolled type 2 diabetes: the DURATION-7 randomized study. Diabetes Obes Metab. 2018;20(7):1602-14.

23. Frías JP, Guja C, Hardy E, et al. Exenatide once weekly plus dapagliflozin once daily versus exenatide or dapagliflozin alone in patients with type 2 diabetes inadequately controlled with metformin monotherapy (DURATION-8): a 28 week, multicentre, double-blind, phase 3, randomised controlled trial. Lancet Diabetes Endocrinol. 2016;4(12):1004-16.

24. Wysham C, Blevins T, Arakaki R, et al. Efficacy and safety of dulaglutide added onto pioglitazone and metformin versus exenatide in type 2 diabetes in a randomized controlled trial (AWARD-1). Diabetes Care. 2014;37(8):2159-67.

25. Giorgino F, Benroubi M, Sun JH, Zimmermann AG, Pechtner V. Efficacy and safety of once-weekly dulaglutide versus insulin glargine in patients with type 2 diabetes on metformin and glimepiride (AWARD-2). Diabetes Care. 2015;38(12):2241-49.
26. Umpierrez G, Tofé Povedano S, Pérez Manghi F, Shurzinske L, Pechtner $\mathrm{V}$. Efficacy and safety of dulaglutide monotherapy versus metformin in type 2 diabetes in a randomized controlled trial (AWARD-3). Diabetes Care. 2014;37(8):2168-76

27. Blonde L, Jendle J, Gross J, et al. Once-weekly dulaglutide versus bedtime insulin glargine, both in combination with prandial insulin lispro, in patients with type 2 diabetes (AWARD-4): a randomised, open-label, phase 3, non-inferiority study. Lancet. 2015;385(9982):2057-66.

28. Nauck M, Weinstock RS, Umpierrez GE, Guerci B, Skrivanek Z, Milicevic Z. Efficacy and safety of dulaglutide versus sitagliptin after 52 weeks in type 2 diabetes in a randomized controlled trial (AWARD-5). Diabetes Care. 2014;37(8):2149-58.

29. Dungan KM, Povedano ST, Forst T, et al. Once-weekly dulaglutide versus once-daily liraglutide in metformin-treated patients with type 2 diabetes (AWARD-6): a randomised, open-label, phase 3, non-inferiority trial. Lancet. 2014:384(9951):1349-57.

30. Dungan KM, Weitgasser R, Perez Manghi F, et al. A 24-week study to evaluate the efficacy and safety of once-weekly dulaglutide added on to glimepiride in type 2 diabetes (AWARD-8). Diabetes Obes Metab. 2016;18(5):475-82.

31. Pozzilli P, Norwood P, Jódar E, et al. Placebo-controlled, randomized trial of the addition of once-weekly glucagon-like peptide-1 receptor agonist dulaglutide to titrated daily insulin glargine in patients with type 2 diabetes (AWARD-9). Diabetes Obes Metab. 2017;19(7):1024-31.

32. Sorli C, Harashima SI, Tsoukas GM, et al. Efficacy and safety of onceweekly semaglutide monotherapy versus placebo in patients with type 2 diabetes (SUSTAIN 1): a double-blind, randomised, placebo-controlled, parallel-group, multinational, multicentre phase 3a trial. Lancet Diabetes Endocrinol. 2017;5(4):251-60.

33. Ahrén B, Masmiquel L, Kumar H, et al. Efficacy and safety of onceweekly semaglutide versus once-daily sitagliptin as an add-on to metformin, thiazolidinediones, or both, in patients with type 2 diabetes (SUSTAIN 2): a 56-week, double-blind, phase 3a, randomised trial. Lancet Diabetes Endocrinol. 2017;5(5):341-54.

34. Ahmann A, Capehorn M, Charpentier G, et al. Efficacy and safety of once-weekly semaglutide versus exenatide ER in subjects with type 2 diabetes (SUSTAIN 3): a 56-week, open-label, randomized clinical trial. Diabetes Care. 2018;41(2):258-66.

35. Aroda VR, Bain SC, Cariou B, et al. Efficacy and safety of once-weekly semaglutide versus once-daily insulin glargine as add-on to metformin (with or without sulfonylureas) in insulin-naive patients with type 2 diabetes (SUSTAIN 4): a randomised, open-label, parallel-group, multicentre, multinational, phase 3a trial. Lancet Diabetes Endocrinol. 2017;5(5):355-66.

36. Rodbard H, Lingvay I, Reed J, et al. Semaglutide added to basal insulin in type 2 diabetes (SUSTAIN 5): a randomized, controlled trial. J Clin Endocrinol Metab. 2018;103(6):2291-301.

37. Pratley RE, Aroda VR, Lingvay I, et al.; SUSTAIN 7 investigators. Semaglutide versus dulaglutide once weekly in patients with type 2 diabetes (SUSTAIN 7): a randomised, open-label, phase 3b trial. Lancet Diabetes Endocrinol. 2018;6(4):275-86.

38. Karagiannis T, Liakos A, Bekiari E, et al. Efficacy and safety of onceweekly glucagon-like peptide 1 receptor agonists for the management of type 2 diabetes: a systematic review and meta-analysis of randomized controlled trials. Diabetes Obes Metab. 2015;17(11):1065-74.

39. Kayaniyil S, Lozano-Ortega G, Bennett HA, et al. A network meta-analysis comparing exenatide once weekly with other GLP-1 receptor agonists for the treatment of type 2 diabetes mellitus. Diabetes Ther. 2016;7(1):27-43.

40. Li J, Zheng J, Wang S, Lau HK, Faithi A, Wang Q. Cardiovascular benefits of native GLP-1 and its metabolites: an indicator for GLP-1-therapy strategies. Front Physiol. 2017;8:15. 
41. Orme ME, Nguyen H, Lu JY, Thomas SA. Comparative effectiveness of glycemic control in patients with type 2 diabetes treated with GLP-1 receptor agonists: a network meta-analysis of placebo-controlled and active-comparator trials. Diabetes Metab Syndr Obes. 2017;10:111-22.

42. Htike ZZ, Zaccardi F, Papamargaritis D, Webb DR, Khunti K, Davies MJ. Efficacy and safety of glucagon-like peptide-l receptor agonists in type 2 diabetes: a systematic review and mixed-treatment comparison analysis. Diabetes Obes Metab. 2017;19(4):524-36.

43. Hauber AB, Nguyen H, Posner J, Kalsekar I, Ruggles J. A discrete-choice experiment to quantify patient preferences for frequency of glucagon-like peptide-1 receptor agonist injections in the treatment of type 2 diabetes. Curr Med Res Opin. 2016;32(2):251-62.

44. Gelhorn HL, Poon JL, Davies EW, Paczkowski R, Curtis SE, Boye KS. Evaluating preferences for profiles of GLP-1 receptor agonists among injection-naïve type 2 diabetes patients in the UK. Patient Prefer Adherence. 2015;9:1611-22.

45. Qin L, Chen S, Flood E, et al. Glucagon-like peptide-1 receptor agonist treatment attributes important to injection-naïve patients with type 2 diabetes mellitus: a multinational preference study. Diabetes Ther. 2017;8(2):321-34.
46. Qin L, Chen S, Flood E, et al. Glucagon-like peptide-1 receptor agonist treatment attributes important to injection-experienced patients with type 2 diabetes mellitus: a preference study in Germany and the United Kingdom. Diabetes Ther. 2017;8(2):335-53.

47. Guo XH. The value of short- and long-acting glucagon-like peptide-1 agonists in the management of type 2 diabetes mellitus: experience with exenatide. Curr Med Res Opin. 2016;32(1):61-76.

48. Uccellatore A, Genovese S, Dicembrini I, Mannucci E, Ceriello A. Comparison review of short-acting and long-acting glucagon-like peptide-1 receptor agonists. Diabetes Ther. 2015;6(3):239-56.

49. Madsbad S. Review of head-to-head comparisons of glucagon-like peptide-1 receptor agonists. Diabetes Obes Metab. 2016;18(4):317-32.

50. Alatorre C, Fernández Landó L, Yu M, et al. Treatment patterns in patients with type 2 diabetes mellitus treated with glucagon-like peptide-1 receptor agonists: higher adherence and persistence with dulaglutide compared with once-weekly exenatide and liraglutide. Diabetes Obes Metab. 2017;19(7):953-61.

51. Nguyen H, Dufour R, Caldwell-Tarr A. Glucagon-like peptide-1 receptor agonist (GLP-1RA) therapy adherence for patients with type 2 diabetes in a Medicare population. Adv Ther. 2017;34(3):658-73. 